INSTITUTO DE PESQUISAS ENERGÉTICAS E NUCLEARES

AUTARQUIA ASSOCIADA À UNIVERSIDADE DE SÃO PAULO

\title{
SECREÇÃO DE HORMÔNIO DE CRESCIMENTO DE CAMUNDONGO POR QUERATINÓCITOS HUMANOS PRIMÁRIOS: PERSPECTIVAS PARA UM MODELO ANIMAL DE TERAPIA GÊNICA CUTÂNEA
}

\section{CLÁUDIA REGINA CECCHI}

\begin{abstract}
Dissertação apresentada como parte dos requisitos para obtenção do Grau de Mestre em Ciências na Área de Tecnologia Nuclear - Aplicações
\end{abstract}

Orientadora:

Dra. Cibele Nunes Peroni

São Paulo

2008 
INSTITUTO DE PESQUISAS ENERGÉTICAS E NUCLEARES

AUTARQUIA ASSOCIADA À UNIVERSIDADE DE SÃO PAULO

\title{
SECREÇÃO DE HORMÔNIO DE CRESCIMENTO DE CAMUNDONGO POR QUERATINÓCITOS HUMANOS PRIMÁRIOS: PERSPECTIVAS PARA UM MODELO ANIMAL DE TERAPIA GÊNICA CUTÂNEA
}

\section{CLÁUDIA REGINA CECCHI}

\begin{abstract}
Dissertação apresentada como parte dos requisitos para obtenção do Grau de Mestre em Ciências na Área de Tecnologia Nuclear - Aplicações
\end{abstract}

Orientadora:

Dra. Cibele Nunes Peroni

São Paulo

2008 
Aos meus pais José Augusto Cecchi (in memoriam) e Suely Mitie Fujita Cecchi, por todo amor e dedicação, por nunca me deixarem desistir, e me ensinarem o que é a determinação; A minha avó Lourdes Bertoldo Cecchi, por todo apoio incondicional aos meus estudos e por acreditar sempre em mim;

E a minha irmã Michelle Cecchi, por todo carinho e compreensão. 


\section{$\underline{\text { Agradecimentos }}$}

Agradeço primeiramente a minha orientadora e mestra Dra. Cibele Nunes Peroni, a quem devo respeito e tenho muita admiração por tudo que aprendi durante esses anos, por todas as broncas que serviram de lição, por toda paciência que teve comigo e pela grande amizade construída.

Ao Dr. Paolo Bartolini, meu co-orientador, pelos ensinamentos, por toda seriedade que me ajudou no meu amadurecimento como pessoa, pela confiança e por toda contribuição científica para realização deste trabalho.

A Dra. Teresa Carvalho Pinto Ribela, por seu colo de mãe, seus conselhos e todos os seus abraços de conforto durante essa longa caminhada.

Ao Dr. Carlos Roberto Jorge Soares, pelo apoio, incentivo e alegria contagiante.

A Dra. Kayo Okazaki, pelos ensinamentos e sabedoria compartilhada.

A Dr. Enrique Boccardo, Dra. Luisa Lina Villa, Suely Nonogaki e demais técnicos do Instituto Ludwig por toda colaboração para complementação deste trabalho.

À minhas irmãs e irmão do coração, Renata Martinussi, Flavia Valgode, Taís Lima, Natália Malavasi e Eric Ueda, por toda a amizade consolidada, por toda ajuda, por estarem presentes em todos os momentos bons e nunca me abandonarem nos ruins...

Ao João Ezequiel Oliveira, Miriam Suzuki, Nélio Oliveira, Elisa Higuti e Renata Damiani por toda força e ajuda diretamente neste trabalho e grande amizade... 
À Maria Neide Mascarenhas, por me ensinar a manipular os animais, pelo auxílio e pela amizade construída.

À Fernanda de Mendonça, Márcia Augusta, Cristiane Moreira, Susana Heller Walter Hirata, Antônio Carlos Junqueira, José Maria de Souza, Adriana Ozaki, Geyza Spigotti, Beatriz Almeida, Sueli Venâncio, Renan Loureiro, Diane Belchior, Rosângela Arkaten, Hebert Goulart, Fernanda Arthuso, Dirce Pinto e Arlete Correia pela amizade e alegria diariamente transmitida.

À Edna, Bernadete, Néia, pela amizade, alegria, apoio... e limpeza dos laboratórios, materiais, do meu cantinho da sala e por sempre arrumarem minha bagunça da mesa.

A Elizabeth Somessari, Carlos Gaia e Hélio Paes, do Centro de Tecnologia das Radiações (CTR-IPEN), pela disponibilidade para as irradiações das células...

À Dra. Nanci do Nascimento, Dra. Lígia Morganti, Lucélia, Janaína, Alberto, Murilo, Danielle, Felipe, Marcos, Jean, Rosa, Eduardo, Rodrigo, Solange, Camila e aos demais colegas do Centro de Biotecnologia pelos momentos de descontração durante as festas e almoços.

Ao Instituto de Pesquisas Energéticas e Nucleares, e a Comissão Nacional de Energia Nuclear, pela oportunidade de realizar este trabalho e pelo auxílio financeiro.

A toda minha família Cecchi e Fujita... principalmente minha madrinha Regina Maria Cecchi Ferreira da Costa e meu avô Agostinho Bastos Lemos (in memoriam), por me ensinar que o estudo é a alma da vida, e que conhecimento nunca é demais. 
Aos meus amigos: Adriano Zager, Alberto Perchiavalli, Alcino Golegã, Ana Claudia Mandolesi, André Gibbon, André Silveira, André Takatsu, Antônio Celso Coradini Júnior, Arianne Silva, Ariel Cardoso, Beatriz Aguiar, Bruna Malagoli, Brunno Ferraz, Bruno Boscarato, Carlos Antonio Vergara, Carolina Bastos, Cauê Magnani, Daniela Zuppani, Edilson Dantas, Emerson Kenji, Fanny Tzelepis, Fernando de Souza, Fernando Mesquita, Fernando Salicete, Gabriela Cabral, Gianlucca Nicastro, Giuliana Marques, Gustavo Baltazar, Isis Oliveira, Juliana Simões, Karla Alves, Larissa Meyer, Leandro Henrique Alves, Luciana Almeida, Marcos Parmesan, Mariah Munhoz, Mariana Kair, Marianny Passos, Marina Reis, Michel Barros, Moacir Gabriel, Odevani Barros, Paula Catib, Paulo Nasser, Rafael Frias Ovies, Rafael Salerno, Rafael Sanfurgo, Rejane Vasquez, Rodrigo Pacheco, Rodrigo Réssio, Ronaldo Anunciação Júnior, Tânia Barcellos, Talita Conde, Victor Proença e Vinicius Rodrigues, por fazerem esses longos anos passarem mais rápidos, por todos os brindes a verdadeira amizade e à vida. 
"O saber a gente aprende com os mestres e com os livros. A sabedoria, se aprende é com a vida e com os humildes." 


\title{
SECREÇÃO DE HORMÔNIO DE CRESCIMENTO DE CAMUNDONGO POR QUERATINÓCITOS HUMANOS PRIMÁRIOS: PERSPECTIVAS PARA UM MODELO ANIMAL DE TERAPIA GÊNICA CUTÂNEA
}

\author{
Cláudia Regina Cecchi
}

\begin{abstract}
RESUMO
Queratinócitos são um veículo bastante atrativo para a transferência gênica ex vivo e liberação sistêmica uma vez que as proteínas secretadas por estas células podem atingir a circulação via um mecanismo similar ao processo natural.

Um eficiente vetor retroviral (LXSN) contendo o gene do hormônio de crescimento de camundongo $(\mathrm{mGH})$ foi utilizado para transduzir queratinócitos humanos primários.

Os queratinócitos transduzidos apresentaram um nível de secreção in vitro

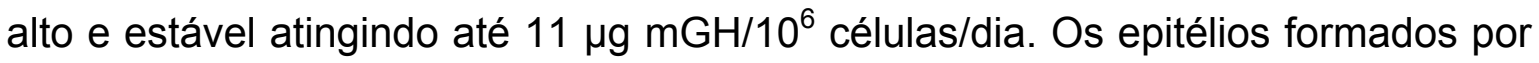
estes queratinócitos geneticamente modificados apresentaram, porém, uma queda na taxa de secreção $>80 \%$ quando foram retirados da placa de cultura utilizando um procedimento clássico. A substituição desta metodologia clássica por uma cultura organotípica resolveu completamente este problema. Camundongos anões imunodeficientes (lit/scid) implantados com estes enxertos organotípicos foram acompanhados durante 4 meses, e apresentaram um aumento de peso significativo $(P<0,05)$ nos primeiros 40 dias. Níveis circulatórios de $\mathrm{mGH}$ atingiram um pico de $21 \mathrm{ng} / \mathrm{mL} 1 \mathrm{~h}$ após o implante, mas estes níveis rapidamente atingiram níveis basais $(\sim 2 \mathrm{ng} / \mathrm{mL})$.

Os queratinócitos humanos primários apresentaram portanto altos níveis de expressão in vitro e os maiores níveis circulatórios, porém por um breve período de tempo, reportados até o momento para GH neste tipo de células. Em conjunto com resultados que mostraram uma recuperação considerável da eficiência de secreção de mGH em cultura por enxertos organotípicos retirados dos animais, foram discutidos os fatores que ainda impedem a utilização clínica deste modelo promissor de terapia gênica cutânea.
\end{abstract}




\title{
SECRETION OF MOUSE GROWTH HORMONE BY TRANSDUCED PRIMARY HUMAN KERATINOCYTES: PROSPECTS FOR AN ANIMAL MODEL OF CUTANEOUS GENE THERAPY
}

\author{
Cláudia Regina Cecchi
}

\begin{abstract}
Keratinocytes are a very attractive vehicle for ex vivo gene transfer and systemic delivery, since proteins secreted by these cells may reach the circulation via a mechanism which mimics the natural process.

An efficient retroviral vector (LXSN) encoding the mouse growth hormone gene $(\mathrm{mGH})$ was used to transduce primary human keratinocytes. Organotypic raft cultures were prepared with these genetically modified keratinocytes and were grafted onto immunodeficient dwarf mice (lit/scid).

Transduced keratinocytes presented a high and stable in vitro secretion level of up to $11 \mu \mathrm{g} \mathrm{mGH} / 10^{6}$ cells/day. Conventional epidermal sheets made with these genetically modified keratinocytes, however, showed a drop in secretion rates of $>80 \%$ simply due to detachment of the epithelium from its substratum. Substitution of conventional grafting methodologies with organotypic raft cultures completely overcame this problem. The stable long-term grafting of such cultures onto immunodeficient dwarf (lit/scid) mice could be followed for more than 4 months, and a significant weight increase $(P<0.05)$ over the control group was observed in the first 40 days. Circulating $\mathrm{mGH}$ levels revealed a peak of $21 \mathrm{ng} / \mathrm{mL}$ just $1 \mathrm{~h}$ after grafting, but unfortunately these levels rapidly fell to baseline values ( $2 \mathrm{ng} / \mathrm{mL})$.

$\mathrm{mGH}$-secreting primary human keratinocytes presented the highest in vitro expression and peak circulatory levels reported to date for a form of $\mathrm{GH}$ with this type of cells. Together with data showing that excised implants can recover in culture a remarkable fraction of their original in vitro $\mathrm{mGH}$ secretion efficiency, the factors that might still hamper the success of this promising model of cutaneous gene therapy are discussed.
\end{abstract}




\section{SUMÁRIO}

1 INTRODUÇÃO

2 OBJETIVOS

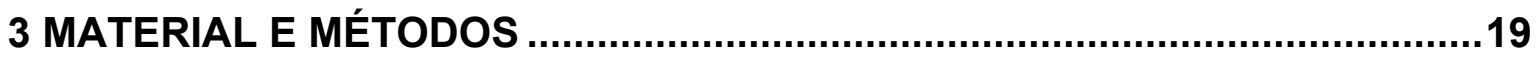

3.1 MATERIAL 19

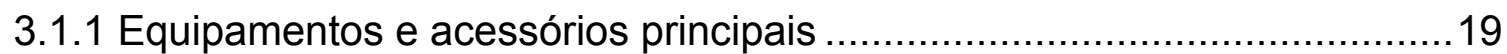

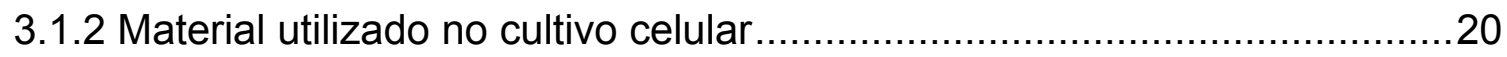

3.1.3 Material plástico estéril para cultura celular .........................................21

3.1.4 Preparações padrão, antissoros e reagentes para radioimunoensaios ....21

3.1.5 Principais reagentes para imunohistoquímica ......................................22

3.1.6 Principais reagentes para biologia molecular.....................................23

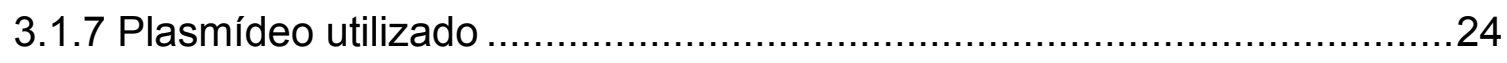

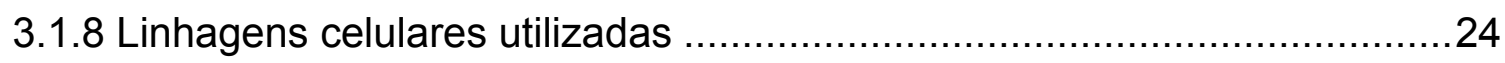

3.1.8.1 Fibroblastos GP+E86 e GP+ENV+AM12 ….........................24

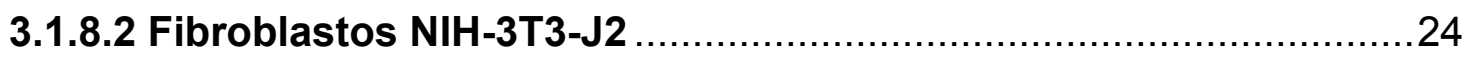

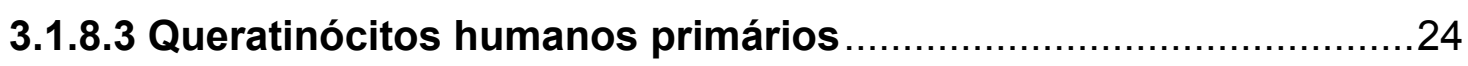

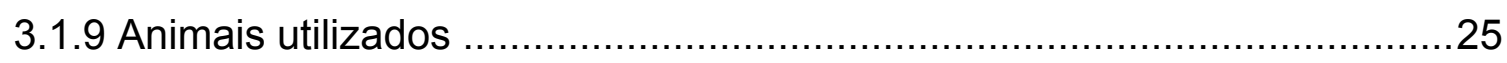

3.1.9.1 Camundongos da linhagem C57BL/6J-GHRHR ${ }^{\mathrm{LIT} /+}$ (lit/lit) ...........25

3.1.9.2 Camundongos da linhagem B6;CB17-Ghrhr ${ }^{\text {lit//+Prkdc }}$ scid/BM

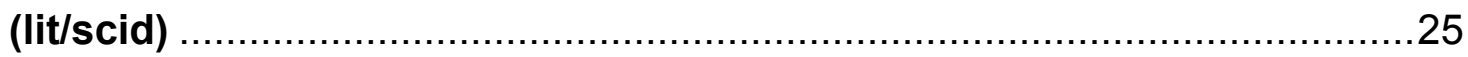

3.2 MÉTODOS 26

3.2.1 Construção do vetor de expressão retroviral pLmGHSN e transdução dos

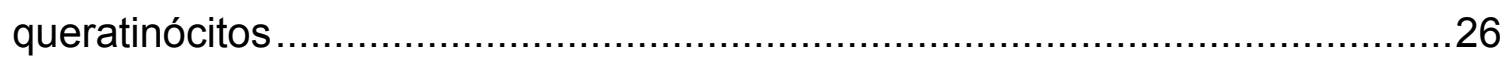

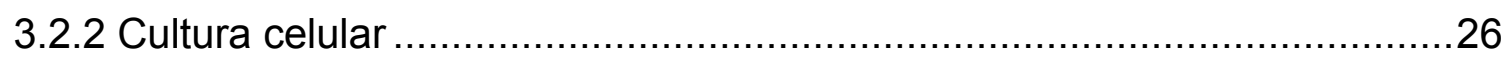

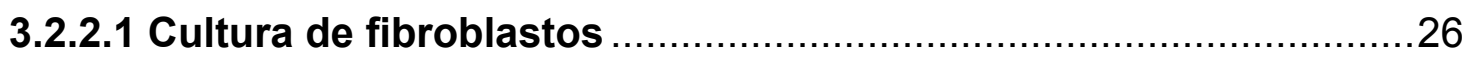

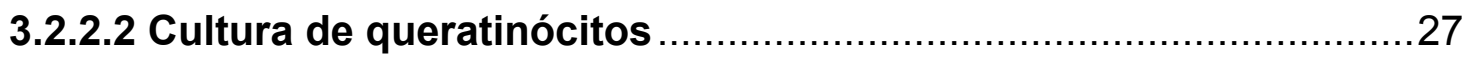

3.2.3 Radioimunoensaio (RIA) para quantificação de $\mathrm{mGH}$ e de $\mathrm{hGH}$.............27

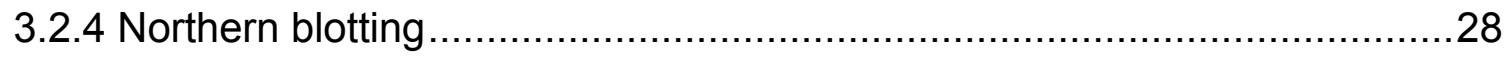

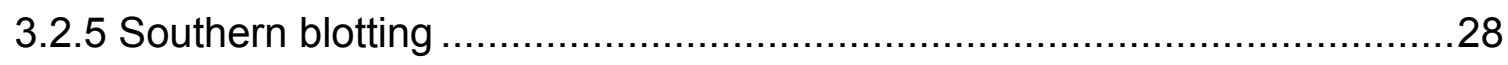

3.2.6 Obtenção do epitélio a partir da placa de cultura .....................................29

3.2.7 Construção da cultura celular organotípica ...........................................29 
3.2.8 Implante da cultura celular organotípica em camundongos anões

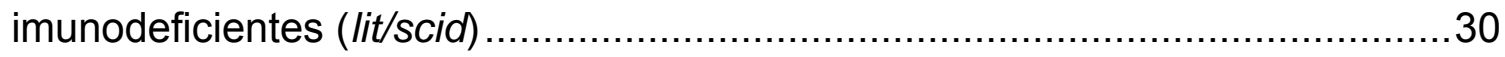

3.2.9 Inoculação de $\mathrm{mGH}$ via subcutânea .............................................. 31

3.2.10 Cultura dos epitélios retirados após implante.................................. 31

3.2.11 Imunohistoquímica dos epitélios retirados após implante ......................31

3.2.12 Determinação da porcentagem de células-tronco de queratinócitos transduzidos

3.2.13 Determinação da meia-vida circulatória $\left(t_{1 / 2}\right)$ do $\mathrm{mGH}$ e do hGH em camundongos anões (lit/lit)

4 RESULTADOS

4.1 Secreção de $\mathrm{mGH}$ in vitro por queratinócitos transduzidos 34

4.1.1 Funcionamento de culturas organotípicas ........................................ 34

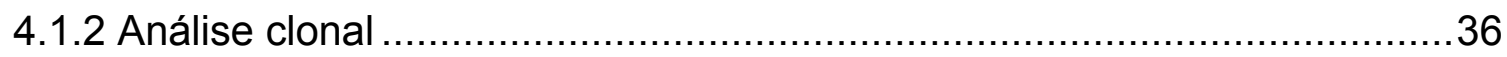

4.1.3 Análise mediante Northern blotting ............................................ 37

4.2 Secreção de $\mathrm{mGH}$ in vivo por queratinócitos transduzidos 38

4.2.1 Ensaio de longa duração................................................................ 38

4.2.2 Estudo da dinâmica de secreção in vivo ............................................ 39

4.2.3 Comparação entre enxertos organotípicos e administração subcutânea de

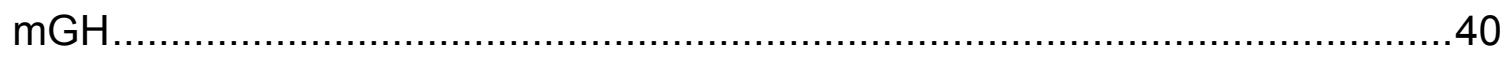

4.2.4 Retirada dos enxertos após uma semana de implante .........................41

4.2.5 Análise imunohistoquímica dos enxertos .............................................42

4.2.6 Análise por Southern blot 43

4.3 Determinação da meia-vida circulatória $\left(t_{1 / 2}\right)$ do $\mathrm{mGH}$ e do $\mathrm{hGH}$ em camundongos anões (lit/lit) 44

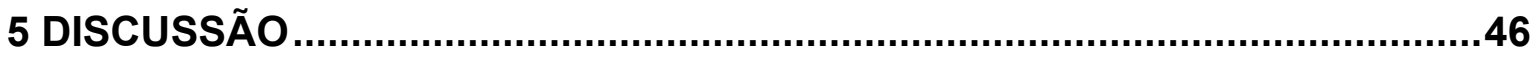

6 REFERÊNCIAS BIBLIOGRÁFICAS.....................................................51 


\section{INTRODUÇÃO}

A terapia gênica pode ser definida como um método para tratar ou prevenir doenças, baseado na transferência de material genético, substituindo genes defeituosos ou ausentes por outros novos, ou pela mudança do perfil de expressão de um gene de interesse (Edelstein e col., 2004; Peroni e col., 2005; Van Gaal e col., 2006). É uma estratégia terapêutica baseada na inserção de um gene (transgene) no interior de uma célula destinatária, tradicionalmente considerada uma modalidade de tratamento para pacientes com vida ameaçada por defeitos congênitos de funções metabólicas ou pacientes em estágio avançado de malignidades (Bransky e col., 2007). Atualmente, a utilização da terapia gênica também tem sido discutida no âmbito da melhora do desempenho e da aparência, tais como aumento da massa muscular, resistência física, memória, controle de peso e de altura e crescimento capilar (Kiuru e Crystal, 2008). Com esse espectro tão amplo, novos sistemas são desenvolvidos para permitir a liberação de proteínas, mediante utilização de genes que codificam hormônios, citocinas, anticorpos, antígenos ou novas proteínas recombinantes.

O gene de interesse (transgene) é transportado por um vetor e está contido em um fragmento de DNA ou RNA, que carrega ainda outros elementos genéticos importantes para sua manutenção e expressão. As formas de transferência deste vetor contendo o gene são muito variadas. Algumas utilizam o vírus como veículo transportador, mais especificamente retrovírus, adenovírus e vírus adeno-associados. Outras formas possíveis de transferência são as técnicas não-virais, que incluem a injeção direta do plasmídeo (naked DNA), métodos físicos como eletroporação e biobalística e métodos químicos, como a lipofecção (Nardi e col., 2002).

A terapia gênica é caracterizada por dois grupos distintos, a terapia gênica somática (com modificações genéticas em qualquer tipo de célula adulta) e a terapia gênica germinativa (que modifica somente células da linhagem germinativa). Esta última é, portanto, uma esperança de tratamento para um grande número de doenças até hoje consideradas incuráveis por métodos convencionais, mas que ainda apresenta grandes barreiras de ordem ético-social. A maioria dos experimentos clínicos atuais está direcionada para o tratamento de 
doenças adquiridas, doenças cardiovasculares e diversos tipos de câncer (mama, próstata, ovário, pulmão e leucemias).

Como toda nova proposta de tratamento, a terapia gênica deve ser testada em protocolos pré-clínicos, com estudos in vitro, seguidos por experimentação em modelos animais e só após em protocolos clínicos, seguindo uma série de etapas envolvendo pacientes (Nardi e col., 2002).

De acordo com o National Institute of Health (NIH - Bethesda, MD, EUA), já foram aprovados 1.411 testes clínicos para terapia gênica em diversos campos terapêuticos, onde 827 ainda estão abertos a procura de pacientes para completar esses estudos. Na Fig. 1, observamos a distribuição mundial dos testes clínicos apresentada no site americano ClinicalTrials.gov ${ }^{1}$, em 156 diferentes países.

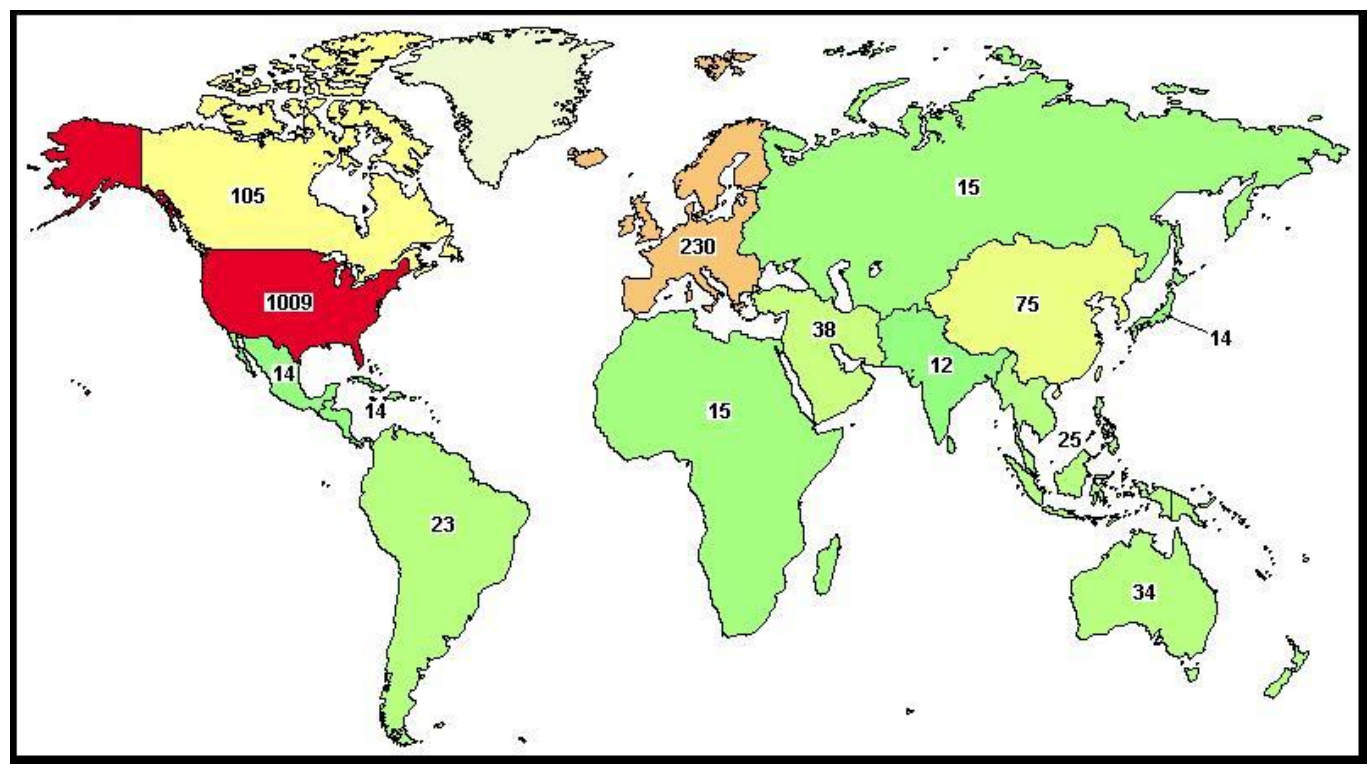

Fig.1: Distribuição mundial dos testes clínicos de acordo com o NIH.

O primeiro teste clínico terapêutico foi realizado em 1990, por Blaese e col. (1995), para corrigir a deficiência da enzima adenosina deaminase (ADA), capaz de comprometer o sistema imunológico causando uma imunodeficiência severa combinada (SCID). Mais tarde, o grupo de Cavazzana-Calvo e col. (2000), realizou um teste clínico para o tratamento da imunodeficiência severa combinada associada ao cromossomo $X(X$-linked-SCID) causada pela mutação do gene IL2RG, e que acomete apenas indivíduos do sexo masculino. Foi obtido um impressionante sucesso até que duas, das onze crianças tratadas com esta terapia genética desenvolveram leucemia pelo fato do vetor retroviral ter se 
integrado próximo ao promotor do proto-oncogene LMO2, o qual induziu sua transcrição e expressão de forma aberrante (Hacein-Bey-Abina e col.; 2003a, 2003b). Este grave incidente, em conjunto com a morte de um jovem atribuída a uma severa reação inflamatória a um vetor adenoviral (Raper e col., 2003), acarretou uma redução drástica do número de testes clínicos neste início de século. Consequentemente, as agências regulatórias internacionais tornaram-se mais rigorosas na liberação dos protocolos em termos de segurança, os quais sofreram atrasos consideráveis devido principalmente ao fato dos vetores de expressão terem que ser reformulados no sentido de diminuir toxicidade, imunogenicidade e potencial inflamatório (Amalfitano, 2003; St. George, 2003; Tomanin e Scarpa, 2004; Ferrari e col., 2005; Yi e col. 2005).

Diversos tipos de terapia genética são descritas, entre elas a terapia gênica cutânea, considerada um método alternativo potencialmente atrativo para o tratamento de deficiências, hereditárias ou adquiridas, de alguns tipos de proteínas circulantes, como o tratamento de deficiência de hormônio de crescimento $(\mathrm{GH})$, para o qual várias estratégias de transferência ex vivo e in vivo do gene deste hormônio em diferentes modelos animais têm sido utilizadas, com resultados bastante satisfatórios (Peroni e col., 2005).

Atualmente, o único tratamento para esse tipo de deficiência é a administração de $\mathrm{GH}$ exógeno, mas apresenta uma série de dificuldades, entre elas o alto custo do tratamento. Um paciente que necessita do tratamento com hGH recombinante gasta em média mais de 20 mil dólares por ano, portanto a síntese deste hormônio in vivo pode oferecer um benefício também do ponto de vista financeiro (Al-Hendy e col., 1996; Rivera e col., 1999; Marmary e col., 1999; Sondergaard e col., 2003; Peroni e col., 2005).

Além disso, o tratamento da deficiência de GH utilizando transferência gênica apresenta a possibilidade de eliminar os inconvenientes das repetidas injeções da terapia convencional com administração do hormônio recombinante. Deste modo, indubitavelmente não haveria a necessidade dos desgastantes e dispendiosos processos de purificação de uma proteína recombinante e, especialmente, os mecanismos de liberação in vivo da proteína de interesse seriam mais similares ao processo fisiológico natural do organismo humano (Morgan e Anderson, 1993; Heartlein e col., 1994; Krueger e col., 1999; Taichman, 1999; Peroni e col., 2005). 
Um dos tecidos-alvo mais atrativos para terapia gênica somática incluindo manipulações genéticas é a pele, por suas células serem de fácil acessibilidade e transdução, fácil monitoramento para reações adversas e pelo alto número de doenças que podem ser amenizadas utilizando a terapia gênica cutânea, incluindo desde doenças monogênicas da pele até doenças sistêmicas (De Luca e Pelegrini, 1997; Taichman, 1999; Jensen e col., 1994; Hengge e Bardenheuer, 2004; Jensen, 2004a e 2004b; Mavilio e col., 2006; Branski e col., 2007; Kikuchi e col., 2007; Peroni e col., 2008).

Uma das estratégias mais utilizadas para terapia gênica cutânea baseia-se na modificação genética de queratinócitos humanos, as células mais abundantes da epiderme, que desta maneira tornam-se capazes de produzir e secretar as proteínas de interesse terapêutico com efeito sistêmico (De Luca e Pellegrini, 1997; Taichman, 1999). Os queratinócitos constituem a principal população de células da epiderme, e podem ser cultivados sob condições apropriadas de cultura. Dessa maneira, reconstituem in vitro um epitélio transplantável, mantendo as mesmas características de diferenciação e o mesmo padrão de expressão gênica de seus correspondentes in vivo (Green e col., 1979).

Um dos principais veículos de transferência gênica cutânea para células de mamífero são os vetores virais, destacando-se os retrovirais por serem de relativa facilidade para construção, possuir uma capacidade de clonagem suficiente para vários genes terapêuticos e integrarem-se ao genoma do hospedeiro (Miller e col., 1993; Robbins e col., 1998).

Todos os sistemas virais utilizados baseiam-se em vírus deficientes em replicação, portanto são capazes de transferir seu material genético para as células-alvo, mas não conseguem replicar-se e continuar seu ciclo infeccioso (Romano e col., 2000; Nardi e col., 2002). Entretanto, esta estratégia de terapia gênica cutânea ainda apresenta um importante obstáculo, que é a obtenção de níveis terapêuticos sustentáveis de secreção do transgene in vivo (Taichman, 1999; Ferrari e col., 2006). Esta expressão não duradoura e a ausência de mecanismos precisos de regulação do gene de interesse na célula-alvo também dificultam ainda mais o avanço da terapia gênica como ferramenta terapêutica.

O primeiro sucesso da terapia gênica utilizando queratinócitos, foi descrito por Mavilio e col. (2006), que obteve a correção gênica da epidermólise 
bulhosa juncional (JEB), mediante transplante de queratinócitos modificados pela introdução do gene da laminina-5.

Vários autores já utilizaram queratinócitos contendo o gene do $\mathrm{GH}$ em protocolos de terapia gênica ex vivo, como apresentado na Tab. 1 (Morgan e col., 1987; Teumer e col., 1990; Jensen e col., 1994; Vogt e col., 1994; Bellini e col., 2003; Peroni e col., 2006 e 2008). O grupo de Morgan e col. (1987) realizou os primeiros estudos utilizando queratinócitos humanos primários transduzidos por um vetor retroviral contendo o gene do hGH e obteve uma taxa de secreção in vitro de 0,072 $\mu \mathrm{g} / 10^{6}$ células/dia (Teumer e col., 1990). Apesar de não ter sido detectado hGH na circulação de camundongos atímicos implantados com os queratinócitos transduzidos, os autores enfatizaram que estas células reconstruíram uma epiderme normal capaz de sofrer diferenciação. A seguir, o mesmo grupo (Teumer e col., 1990) utilizou um vetor não viral contendo o gene do hGH para transfectar queratinócitos de uma linhagem estabelecida (SCC-13), derivada de um carcinoma escamoso de epiderme (Rheinwald e Belkett, 1981). Embora um nível de expressão relativamente alto de $5,3 \mu \mathrm{g} \mathrm{hGH} / 10^{6}$ células/dia tenha sido obtido in vitro, os níveis de hormônio circulante em camundongos nude não foram constantes, decaindo de valores iniciais de $\sim 0,6-1,0 \mathrm{ng} / \mathrm{mL}$ a valores indetectáveis 4 semanas após o implante.

Jensen e col. (1994) utilizaram queratinócitos humanos primários transfectados via lipofecção com um vetor de expressão contendo o gene do hGH controlado por um promotor de SV40. Houve detecção do hormônio na circulação durante apenas 4 dias, embora tenha sido obtido um nível relativamente alto de $2,6 \mathrm{ng} / \mathrm{mL}$ em um camundongo implantado, com uma média de 0,6 ng/mL em $\mathrm{n}=5$ camundongos. Em outro estudo (Vogt e col., 1994), queratinócitos porcinos foram transduzidos com um vetor retroviral contendo o gene do hGH e implantados em fluidos de ferida de porcos para criar um tipo de cultura celular in vivo. No fluido foi detectado hGH durante 10 dias com um pico de $0,35 \mathrm{ng} / \mathrm{mL}$ no $6^{\circ}$ dia, cujo desaparecimento coincidiu com o restabelecimento de uma barreira epitelial que provavelmente impediu sua difusão. Os autores sugeriram que este modelo poderia ser útil para a cura de feridas, nas quais é requerida a produção temporária de fatores de crescimento ou proteínas terapêuticas. 
Tabela 1: Principais estudos de terapia gênica para GH utilizando queratinócitos

\begin{tabular}{|c|c|c|c|c|c|c|}
\hline Referência & $\begin{array}{c}\text { Vetor } \\
\text { (promotor) }\end{array}$ & Célula-alvo & Animal & $\begin{array}{c}\text { Expressão } \\
\text { in vitro } \\
\left(\mu \mathrm{g} / 10^{6} \text { céls }\right. \\
\text { /dia })\end{array}$ & $\begin{array}{c}\text { Níveis } \\
\text { circulatórios } \\
\text { de } \mathrm{GH} \\
(\mathrm{ng} / \mathrm{mL})\end{array}$ & $\begin{array}{c}\text { Duração } \\
\text { in vivo } \\
\text { (dias) }\end{array}$ \\
\hline $\begin{array}{l}\text { Morgan e } \\
\text { col. (1987) }\end{array}$ & $\begin{array}{c}\text { DOL-hGH } \\
\text { (LTR) }\end{array}$ & $\mathrm{QHP}^{\mathrm{b}}$ & $\begin{array}{l}\text { Camundongo } \\
\text { nude }\end{array}$ & 0,072 & - & - \\
\hline $\begin{array}{l}\text { Teumer e } \\
\text { col. (1990) }\end{array}$ & $\begin{array}{l}\text { pTKGH } \\
(\text { TK })^{c}\end{array}$ & $\begin{array}{l}\text { Queratinócitos } \\
\text { humanos } \\
\text { (SCC-13) }\end{array}$ & $\begin{array}{c}\text { Camundongo } \\
\text { nude }\end{array}$ & 5,3 & $0,6-1,0$ & 28 \\
\hline $\begin{array}{l}\text { Jensen e } \\
\text { col. (1994) }\end{array}$ & $\begin{array}{c}\text { vetor } \\
\text { baseado em } \\
\text { EBV (SV40) }\end{array}$ & $\mathrm{QHP}^{\mathrm{b}}$ & $\begin{array}{l}\text { Camundongo } \\
\text { nude }\end{array}$ & 0,7 & $\begin{array}{l}2,6(n=1) \\
0,6(n=5)\end{array}$ & 4 \\
\hline $\begin{array}{c}\text { Vogt e col. } \\
(1994)\end{array}$ & $\alpha S G C-h G H^{a}$ & $\begin{array}{l}\text { Queratinócitos } \\
\text { porcinos }\end{array}$ & Porco & $\sim 3 \mathrm{ng} / \mathrm{ml}$ & $0,35^{\mathrm{d}}$ & 10 \\
\hline $\begin{array}{l}\text { Bellini e } \\
\text { col. (2003) }\end{array}$ & $\begin{array}{c}\mathrm{pLhGHSN}^{\mathrm{a}} \\
(\mathrm{LTR})\end{array}$ & $\mathrm{QHP}^{\mathrm{b}}$ & $\begin{array}{l}\text { Camundongo } \\
\text { lit/scid }\end{array}$ & 7 & $0,2-0,3$ & 12 \\
\hline $\begin{array}{l}\text { Peroni e } \\
\text { col. }(2006 \text { e } \\
2008\end{array}$ & $\begin{array}{c}\mathrm{pLmGHSN}^{\mathrm{a}} \\
\text { (LTR) }\end{array}$ & $\mathrm{QHP}^{\mathrm{b}}$ & $\begin{array}{l}\text { Camundongo } \\
\text { lit/scid }\end{array}$ & 11 & 20 & 1 \\
\hline
\end{tabular}

${ }^{a}$ Vetor retroviral; ${ }^{b}$ queratinócitos humanos primários; ${ }^{c}$ promotor de timidina quinase; ${ }^{d}$ no fluido da ferida

Não foi ainda descrita, porém, uma secreção prolongada de hGH in vivo ou um aumento de peso significativo. Este último efeito fenotípico, mesmo limitado, foi reportado pelo nosso grupo de pesquisa (Bellini e col., 2003). Mais recentemente realizamos a construção de um sistema homólogo com o gene do $\mathrm{GH}$ de camundongo $(\mathrm{mGH})$, que havia sido anteriormente utilizado por poucos pesquisadores. Al-Hendy e col. (1995) demonstraram que o $\mathrm{mGH}$ secretado por mioblastos microencapsulados foram capazes de promover um crescimento significativo de camundongos anões (Snell dwarf), enquanto que Marmary e col. (1999), utilizando este mesmo modelo animal, injetaram por via intramuscular um vetor adenoviral contendo o gene do $\mathrm{mGH}$ e obtiveram uma recuperação total do peso corpóreo frente aos camundongos não afetados por um período de tratamento da ordem de 30 dias.

Em nosso laboratório é desenvolvido um modelo de transferência gênica cutânea ex vivo, que utiliza queratinócitos humanos primários transduzidos com um eficiente vetor retroviral (LXSN), contendo o gene do hGH ou do $\mathrm{mGH}$. Esta estratégia permitiu a obtenção do mais alto nível de expressão "in vitro" de 
uma forma de $\mathrm{GH}$ já reportado na literatura empregando este tipo de célula (11 $\mu \mathrm{g}$ $\mathrm{mGH} / 10^{6}$ células/dia) (Rosauro, 2003; Peroni e col., 2006 e 2008), superando até mesmo valores anteriormente obtidos com o gene do hGH (Bellini e col., 2003), como também é apresentado na Tabela 1.

Foi verificado, porém que, quando o epitélio formado por estes queratinócitos transduzidos é retirado da placa de cultura com a utilização da enzima dispase, para ser implantado em camundongos anões imunodeficientes (lit/scid), ocorria uma perda de secreção in vitro maior que $80 \%$. Esta enzima é utilizada para desprender o epitélio da placa de cultura antes do implante nos camundongos, de acordo com procedimento clássico de Barrandon e cols. (1988). Esta mesma metodologia havia sido também utilizada para implantar os queratinócitos secretores de hGH nos camundongos lit/scid, proporcionando níveis circulatórios de 0,2-0,3 $\mathrm{ng} \mathrm{hGH} / \mathrm{mL}$ durante 12 dias com um pico de secreção de $1,5 \mathrm{ng} / \mathrm{mL}$ depois de $4 \mathrm{~h}$ da cirurgia (Bellini e col., 2003).

A técnica de implante foi então alterada mediante a construção de uma cultura celular organotípica, baseada em uma matriz de colágeno e fibroblastos, onde são cultivados os queratinócitos modificados. Com a utilização desta metodologia, houve a manutenção dos níveis de expressão de $\mathrm{mGH}$ in vitro.

Por outro lado, a transdução de células-tronco tem sido considerada um importante pré-requisito para a manutenção da expressão do transgene in vivo (Taichman, 1999; Dunnwald e col., 2001; Peroni e col., 2006; Ferrari e col., 2006). Uma das metodologias utilizadas para a determinação da porcentagem de células-tronco epidermais numa determinada população de queratinócitos transduzidos é a análise clonal, que avalia o potencial de proliferação in vitro destas células (Mathor e col., 1996; Kolodka e col., 1998; Peroni e col., 2006) e verifica se estes clones também mantém a eficiência de expressão durante sucessivas passagens. 


\section{OBJETIVOS}

O objetivo principal do presente trabalho foi a utilização de uma cultura celular organotípica para otimizar as condições de implante de queratinócitos humanos primários transduzidos com o gene do $\mathrm{mGH}$ em camundongos lit/scid, na tentativa de evitar a perda de $80 \%$ da secreção in vitro e de manter por um período mais prolongado a secreção do transgene in vivo. Outros fatores que podem influenciar o tempo de permanência desta secreção, tais como a porcentagem de células-tronco epidermais transduzidas e a meia-vida circulatória do transgene, foram também estudados para ajudar na viabilização deste modelo promissor de terapia gênica cutânea. 


\section{MATERIAL E MÉTODOS}

\subsection{MATERIAL}

\subsubsection{Equipamentos e acessórios principais}

- Agitador magnético modelo 258 - FANEM (São Paulo, SP, Brasil);

- Agitador rotatório tipo vortex, modelo 162 - MARCONI (São Paulo, SP, Brasil);

- Autoclave vertical, modelo 103 - FABBE-PRIMAR (São Paulo, SP, Brasil);

- Balança analítica, modelo H20T - METTLER (Zurich, Suíça);

- Balança analítica, modelo P100N - METTLER (Zurich, Suíça);

- Balança analítica, modelo M5AS - METTLER (Zurich, Suíça);

- Câmera de Neubauer - BOECO (Hamburg, Alemanha);

- Centrífuga, modelo LS-3 plus - CELM (São Paulo, SP, Brasil);

- Centrífuga refrigerada automática modelo Super Speed RC - 2B SORVALL (Newtown, Connecticut, EUA);

- Contador gama tipo "poço", com troca automática de amostra, modelo Cobra auto-gama, eficiência aproximada para ${ }^{125}$ de $80 \%$ - PACKARD INSTRUMENT COMPANY (Illinois, EUA);

- Destilador de água, modelo 016 - FABBE-PRIMAR (São Paulo, SP, Brasil);

- Estufa de cultura celular, modelo 3159 - FORMA SCIENTIFIC (Marietta, Ohio, EUA);

- Fluxo Laminar classe II A/B 3, modelo 1140 - FORMA SCIENTIFIC (Marietta, Ohio, EUA);

- Freezer $-20^{\circ} \mathrm{C}$, modelo 0651 - PROSDÓCIMO (São Paulo, SP, Brasil);

- Freezer $-40^{\circ} \mathrm{C}$, modelo AB 240 - METALFRIO, (São Paulo, SP, Brasil);

- Freezer $-80^{\circ} \mathrm{C}$, modelo 8425 - FORMA SCIENTIFIC (Marietta, Ohio, EUA);

- Medidor digital de pH, modelo 420A - ORION (Boston, MA, EUA);

- Membranas de filtração de 0,22 $\mu \mathrm{m}$ - MILLIPORE (Bedford, MA, EUA);

- Microscópio invertido, modelo ID 03 - CARL ZEISS (Oberkochen, Alemanha); 
- Refrigerador duplex, modelo 320 clear - BRASTEMP (São Paulo, SP, Brasil);

- Sistema de purificação de água Milli-Q plus - MILLIPORE (Bedford, EUA);

- Tubos de poliestireno para imunoensaios $(7,5 \times 1,2 \mathrm{~cm}$ ) - EMTEL (São Paulo, SP, Brasil).

\subsubsection{Material utilizado no cultivo celular}

- Ácido etilenodiaminotetracético (EDTA) - LABSYNTH (São Paulo, SP, Brasil);

- Ácido etanossulfônico hidroxietilpiperazina (HEPES) - SIGMA (St. Louis, MO, EUA);

- Bicarbonato de sódio - LABSYNTH (São Paulo, SP, Brasil);

- Colágeno tipo I da cauda de rato - UPSTATE BIOTECHNOLOGY (Lake Placid , NY, EUA);

- Dimetilsulfóxido (DMSO) - MERCK (São Paulo, SP, Brasil);

- Dispase - INVITROGEN (Carlsbad, CA, EUA);

- Fator de crescimento epitelial humano (hEGF) - INVITROGEN (Carlsbad, CA, EUA);

- Geneticina (G418), Geneticin ${ }^{\circledR}$ - INVITROGEN (Carlsbad, CA, EUA);

- Glicose Anidra - CASA AMERICANA (São Paulo, SP, Brasil);

- Hidrocortisona - CALBIOCHEM - NOVABIOCHEM CORPORATION (La Jolla, CA, EUA);

- Insulina de pâncreas bovino - SIGMA (St. Louis, MO, EUA);

- Meio de Eagle modificado por Dulbecco (DMEM) - INVITROGEN (Carlsbad, CA, EUA);

- Meio Ham - F12 - INVITROGEN (Carlsbad, CA, EUA);

- Penicilina-estreptomicina - INVITROGEN (Carlsbad, CA, EUA);

- Soro de bovino neonato (SBN) - INVITROGEN (Carlsbad, CA, EUA);

- Soro fetal bovino (SFB) - HYCLONE (Logan, UT, EUA);

- Toxina colérica - SIGMA (St. Louis, MO, EUA);

- Tripsina - INVITROGEN (Carlsbad, CA, EUA). 


\subsubsection{Material plástico estéril para cultura celular}

- Garrafas de $75 \mathrm{~cm}^{2}$ - CORNING COSTAR CORP. (NY, EUA);

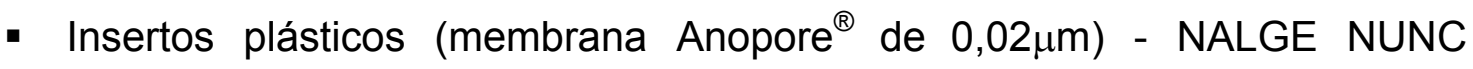
INTERNATIONAL (Rochester, NY, EUA);

- Pipetas de 1, 2, 5, 10 e $25 \mathrm{~mL}$ - CORNING COSTAR CORP. (NY, EUA);

- Placas de 6 poços - CORNING COSTAR CORP. (NY, EUA);

- Placas de 24 poços - CORNING COSTAR CORP. (NY, EUA);

- Placas de $10 \mathrm{~cm}^{2}$ - CORNING COSTAR CORP. (NY, EUA);

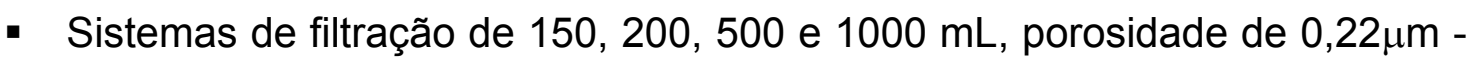
CORNING COSTAR CORP. (NY, EUA);

- Tubos criogênicos de $2 \mathrm{~mL}$ - CORNING COSTAR CORP. (NY, EUA);

- Tubos para centrífuga de 15 e $50 \mathrm{~mL}$ - CORNING COSTAR CORP. (NY, EUA).

\subsubsection{Preparações padrão, antissoros e reagentes para radioimunoensaios}

- Anticorpo policlonal anti-rGH (lote \# AFP5672099), fornecido pelo Dr. A. F. Parlow - NATIONAL HORMONE AND PITUITARY PROGRAM (NHPP, Torrance, CA, EUA);

- Anticorpo policlonal anti-hGH, NIDDK - anti-hGH-2, fornecido pelo Dr. A. F. Parlow - NATIONAL HORMONE AND PITUITARY PROGRAM (NHPP, Torrance, CA, EUA);

- Azida sódica - SIGMA (St. Louis, MO, EUA);

- Controles de qualidade para imunoensaios baseados em sangue humano, Lyphochek I Immunoassay Plus Control (níveis 1,2,3) - BIORAD INVITROGEN (Carslbad, CA, EUA);

- Cloramina T p.a.- MERCK (São Paulo, SP, Brasil);

- Fosfato de sódio bibásico p.a - MERCK (São Paulo, SP, Brasil);

- Fosfato de sódio monobásico p.a - MERCK (São Paulo, SP, Brasil);

- Metabissulfito de sódio - CARLO ERBA (São Paulo, SP, Brasil); 
- $\mathrm{Na}^{125}$ I comercial, livre de carreadores e oxidantes, com atividade específica de 11.100 - $22.200 \mathrm{MBq} / \mathrm{mL}$ (300 - $600 \mathrm{mCi} / \mathrm{mL}$ ) - NORDION EUROPE S.A. (Fleurus, Bélgica);

- Preparação de mGH pituitário (lote \# AFP 10783B) altamente purificada, para iodação, fornecida pelo Dr. A. F. Parlow - NATIONAL HORMONE AND PITUITARY PROGRAM (NHPP, Torrance, CA, EUA);

- Preparação de referência de mGH pituitário (lote \# AFP 10783B), fornecida pelo Dr. A. F. Parlow - NATIONAL HORMONE AND PITUITARY PROGRAM (NHPP, Torrance, CA, EUA);

- Preparação de hGH recombinante altamente purificada para iodação IPEN-CNEN/SP (São Paulo, SP, Brasil) (Ribela e col., 1993; Oliveira e col., 1999);

- Resinas cromatográficas Sephadex G100 - GE HEALTHCARE BIOSCIENCES (Piscataway, NJ, EUA);

- Segundo anticorpo anti-lgG de coelho preparado em carneiro - IPENCNEN/SP (São Paulo, SP, Brasil);

- Soro albumina bovina (BSA), RIA grade (fração V) - SIGMA (St. Louis, MO, EUA);

- Soro de coelho normal - INVITROGEN (Carlsbad, CA, EUA);

- Tween - 20 - SIGMA (St. Louis, MO, EUA).

\subsubsection{Principais reagentes para imunohistoquímica}

- Anticorpo anti-citoqueratina humana de alto peso molecular, clone $34 \beta E 12$ - DAKOCYTOMATION (Carpinteria, CA, EUA);

- Anticorpo anti-involucrina humana - BIOMEDICAL TECHNOLOGIES (Stoughton, MA, EUA);

- Anticorpo anti-mGH para imunocitoquímica (lote \# AFP 5672099 fornecido pelo Dr. A. F. Parlow - NATIONAL HORMONE AND PITUITARY PROGRAM (NHPP, Torrance, CA, EUA);

- Sistema de detecção de anticorpos primários baseado em anticorpo secundário conjugado a um polímero marcado com peroxidase - Envision Plus Systems - DAKOCYTOMATION (Carpinteria, CA, EUA). 
- Sistema de detecção de anticorpos primários baseado em anticorpo secundário conjugado a um polímero marcado com peroxidase SuperPicTure Polymer Detection (cat. 87-9663) - ZYMED LABORATORIES - INVITROGEN IMMUNODETECTION (South San Francisco, CA, EUA).

\subsubsection{Principais reagentes para biologia molecular}

- Agarose - INVITROGEN (Carlsbad, CA, EUA);

- Ampicilina - SIGMA (St. Louis, MO, EUA);

- Brometo de etídio - LKB - PRODUKTER AB (Bromma, Suécia);

- Enzimas de restrição - FERMENTAS (Burlington, Ontário, Canadá);

- Extrato de levedura - DIFCO (São Paulo, SP, Brasil);

- Filtros Hybond N - GE HEALTHCARE BIOSCIENCES (Piscataway, NJ, EUA);

- Hiperfilme Kodak - GE HEALTHCARE BIOSCIENCES (Piscataway, NJ, EUA);

- Marcador de peso molecular lambda DNA / ECORI + HindllI FERMENTAS (Burlington, Ontário, Canadá);

- Micro colunas Illustra G-25 - GE HEALTHCARE BIOSCIENCES (Piscataway, NJ, EUA);

- Nucleotídeo $\left[\alpha-{ }^{32} \mathrm{P}\right]$ dcTP (300 Ci/mmol) - GE HEALTHCARE BIOSCIENCES (Piscataway, NJ, EUA);

- Sistema de marcação de DNA (DNA labeling kit) - GE HEALTHCARE BIOSCIENCES (Piscataway, NJ, EUA);

- Sistema de marcação radioativa de sondas Ready - To - Go Labelling Beads - GE HEALTHCARE BIOSCIENCES (Piscataway, NJ, EUA);

- Sistema para extração de DNA em larga escala QIAGEN Plasmid Maxi Kit QIAGEN (Hilden, Alemanha);

- Sistema para purificação de DNA QIAGEN Quiaquick Nucleotide Removal Kit - QIAGEN (Hilden, Alemanha). 


\subsubsection{Plasmídeo utilizado}

pLmGHSN - plasmídeo construído em nosso laboratório (Peroni e col., 2008), a partir do vetor retroviral pLXSN, no qual foi inserido o cDNA do hormônio de crescimento de camundongo $(\mathrm{mGH})$. Este gene foi obtido do plasmídeo pKLmGH, gentilmente cedido pela Dra. Patrícia L. Chang da Universidade Mc Master (Hamilton, Ontário, Canadá).

\subsubsection{Linhagens celulares utilizadas}

\subsubsection{Fibroblastos GP+E86 e GP+ENV+AM12}

Foram utilizadas as células da linhagem GP+E86, denominadas ecotróficas por sua capacidade de infectar células murinas, e também células da linhagem GP+ENV+AM12, denominadas anfotróficas, pela capacidade de infectar tanto células murinas, como também células humanas (Markowitz e col., 1988a; 1988b). Estas linhagens celulares derivadas de fibroblastos de camundongo $\mathrm{NIH}$ 3T3 co-transfectados com plasmídeos contendo os genes gag, pol e env, foram gentilmente cedidas pelo Dr. Bank da Columbia University (NY, EUA).

\subsubsection{Fibroblastos NIH-3T3-J2}

Estas células são fibroblastos de camundongo, que foram utilizadas como camada de sustentação (feeder layer) para os queratinócitos humanos. A linhagem destas células foi cedida pelo Dr. Carlos Pincelli (Modena, Itália).

\subsubsection{Queratinócitos humanos primários}

São células presentes na camada epidérmica, que foram obtidas a partir de fragmentos de pele humana resultante de cirurgia plástica de mama (mamoplastia) ou a partir de prepúcio de neonatos, de acordo com o protocolo descrito por Green e col. (1979), modificado em nosso laboratório (Rosauro, 2003). 


\subsubsection{Animais utilizados}

Os camundongos das linhagens lit/lit e lit/scid, descritas abaixo, foram adquiridos da empresa THE JACKSON LABORATORY (Bar Harbor, ME, EUA), e as colônias derivadas desses animais são mantidas no biotério do IPEN CNEN/SP (São Paulo, SP, Brasil), nas seguintes condições de criação:

- Temperatura ambiente: $22 \pm 2^{\circ} \mathrm{C}$;

- Iluminação artificial com ciclo circadiano de 12 horas de luz / 12 horas de escuridão;

- Ração e água ad libitum

Os animais da linhagem lit/scid, por apresentarem uma imunodeficiência severa, foram mantidos em microisoladores, dentro de uma área de criação controlada, e todo material utilizado para sua manutenção, bem como a ração e água servidas, foram esterilizados para garantir a saúde desses animais.

\subsubsection{Camundongos da linhagem C57BL/6J-GHRHR ${ }^{\mathrm{LIT}} /+$ (lit/lit)}

Os animais desta linhagem apresentam uma mutação espontânea de origem recessiva, no gene do receptor do fator liberador de $\mathrm{GH}(\mathrm{GHRH})$, localizado no cromossomo 6, que origina o nanismo (Deitel e col., 2002). As características principais das alterações fenotípicas podem ser visualizadas a partir da segunda semana após o nascimento, como a redução da massa corpórea e das dimensões ósseas.

\subsubsection{Camundongos da linhagem B6;CB17-Ghrhr $r^{\text {lit } /+~ P r k d c ~}{ }^{\text {scid/BM }}$ (lit/scid)}

Os camundongos dessa linhagem, além de apresentarem a mutação "lit", descrita anteriormente, apresentam outra mutação autossômica recessiva originada no gene Prkdc, situado no cromossomo 16, que Ihes confere uma imunodeficiência severa. 


\subsection{MÉTODOS}

\subsubsection{Construção do vetor de expressão retroviral pLmGHSN e transdução dos queratinócitos}

Estas etapas já haviam sido realizadas em nosso laboratório (Rosauro, 2003; Peroni e col., 2008). Resumidamente, o vetor retroviral contendo o gene do $\mathrm{mGH}$ foi construído a partir do plasmídeo $\mathrm{pKLmGH}$. O fragmento correspondente ao cDNA do $\mathrm{mGH}$ foi isolado deste plasmídeo e inserido nos sítios de restrição das enzimas Xho I e BamH I do vetor retroviral pLXSN, originando assim o vetor de expressão pLmGHSN.

Este vetor foi introduzido nas células GP+E86, mediante transfecção a partir de co-precipitação do DNA, pelo método do cloreto de cálcio. A seguir, ao sobrenadante destas células ecotróficas foi adicionado polibreno (brometo de hexadimetrina) na concentração de $8 \mu \mathrm{g} / \mathrm{mL}$, para aumentar a permeabilidade da membrana celular. Este sobrenadante foi colocado em contato com as células anfotróficas GP + ENV + AM12, previamente semeadas em placas de cultura, para infecção das mesmas. Os melhores clones destas células selecionados com base na expressão de $\mathrm{mGH}$ (no meio de cultura), determinada por radioimunoensaio e no título viral foram utilizados para a transdução de queratinócitos. Os queratinócitos transduzidos foram selecionados com geneticina (G-418), uma vez que o vetor retroviral contém o gene da neomicina fosfotransferase ("neo"), atingindo níveis de até 11,24 $\pm 1,06 \mu \mathrm{g} \mathrm{mGH} / 10^{6}$ células /dia $(n=6)$. Estes queratinócitos foram congelados para utilização nos experimentos subsequentes.

\subsubsection{Cultura celular}

\subsubsection{Cultura de fibroblastos}

Foram utilizados fibroblastos de camundongos da linhagem NIH - 3T3 J2, que atuam como uma camada de sustentação dos queratinócitos (feeder 
layer) durante o cultivo celular, quando submetidos à irradiação gama em bomba de cobalto $\left(\mathrm{Co}^{60}\right)$ a uma dose de $60 \mathrm{~Gy}$, antes de atingirem a confluência. Estas células foram mantidas em meio de Eagle modificado por Dulbecco (DMEM), acrescido de $10 \%$ de soro de bovino neonato (SBN), penicilina - estreptomicina (100 Ul/mL - $100 \mathrm{pg} / \mathrm{mL}$ ) e tamponado a um pH de 7,2 com HEPES (8 mM). A cultura destas células foi realizada em estufa a $37^{\circ} \mathrm{C}$ e $5 \%$ de $\mathrm{CO}_{2}$.

Para a cultura celular organotípica, foram utilizados fibroblastos humanos, que são cultivados da mesma maneira, com exceção do meio de cultura acrescido de $10 \%$ de soro fetal bovino (SFB).

\subsubsection{Cultura de queratinócitos}

Os queratinócitos humanos foram cultivados no meio apropriado para crescimento destas células (KGM - Keratinocyte Growth Medium), composto por $70 \%$ de meio de Eagle modificado por Dulbecco (DMEM) e 30\% de meio Ham F12. A este meio foram adicionados soro fetal bovino (SFB) a $4 \%$, tampão HEPES $(8 \mathrm{mM})$, toxina colérica $(0,1 \mathrm{nM})$, penicilina-estreptomicina $(100 \mathrm{UI} / \mathrm{mL}-100$ $\mathrm{pg} / \mathrm{mL})$, hidrocortisona $(0,4 \mu \mathrm{g} / \mathrm{mL})$, insulina $(5 \mu \mathrm{g} / \mathrm{mL})$ e fator de crescimento epidermal (EGF) $(10 \mathrm{ng} / \mathrm{mL})$, mantidos em estufa a $37^{\circ} \mathrm{C}$ e $5 \%$ de $\mathrm{CO}_{2}$.

\subsubsection{Radioimunoensaio (RIA) para quantificação de mGH e de hGH}

Para análise quantitativa do hormônio de crescimento humano (hGH) e de camundongo $(\mathrm{mGH})$, durante todas as etapas do presente trabalho, os níveis de expressão in vitro e in vivo destes hormônios foram determinados mediante utilização de radioimunoensaios específicos para estes hormônios, padronizados em nosso laboratório (Bellini e col., 1998; Bellini e col., 2003; Rosauro, 2003; Peroni e col. 2008). As amostras foram analisadas em duplicata, calculando-se $o$ valor médio. Como controle de qualidade, nos ensaios relativos ao $\mathrm{mGH}$ foram utilizados soros com concentração média deste hormônio conhecida, obtidos de camundongos lit/lit $(1,3 \pm 0,7 \mathrm{ng} \mathrm{mGH} / \mathrm{mL} ; \mathrm{n}=8)$ e de camundongos normais da linhagem C57BL6 (6,5 $\pm 1,8 \mathrm{mg} \mathrm{mGH} / \mathrm{mL} ; \mathrm{n}=8)$. No caso do $\mathrm{hGH}$, foram utilizadas preparações comerciais de controle de qualidade (Lyphochek I 
Immunoassay Plus Control) com diferentes concentrações deste hormônio. As sensibilidades dos ensaios foram de $0,25 \mathrm{ng} \mathrm{mGH} / \mathrm{mL}$ e de $0,1 \mathrm{ng} \mathrm{hGH} / \mathrm{mL}$, calculadas de acordo com a definição de Rodbard (1978).

\subsubsection{Northern blotting}

Para a análise por Northern blotting, $10 \mu \mathrm{g}$ de RNA total extraído dos queratinócitos transduzidos e não transduzidos foram fracionados em gel de agarose denaturante a $1 \%$ e transferidos por capilaridade para filtros Hybond $\mathrm{N}$. As técnicas de pré-hibridização, hibridização e lavagens foram realizadas de acordo com o protocolo descrito por Church e Gilbert (1984). A sonda de $\mathrm{mGH}$ foi preparada a partir de um fragmento de cDNA do $\mathrm{mGH}$, retirado do vetor pLmGHSN mediante digestão com as enzimas de restrição Eco $\mathrm{R} I$ e BamH I. Uma sonda de cDNA do gene da enzima GAPDH (Glyceraldehyde-3-Phosphate Dehydrogenase) humana foi utilizada como controle para garantir a mesma quantidade de RNA analisado. Estas sondas foram marcadas utilizando o sistema Ready-To-Go Labelling Beads e [ $\alpha^{32}{ }^{32}$ ] dCTP $(3000 \mathrm{Ci} / \mathrm{mmol})$. Os filtros de nylon foram expostos a um hiperfilme Kodak com tela intensificadora.

\subsubsection{Southern blotting}

O DNA genômico total dos queratinócitos transduzidos e controles (nãotransduzidos), recuperado dos enxertos 0,1 e 7 dias do implante, foi preparado por ressuspensão dos enxertos em tampão de lise ( $\mathrm{NaCl} 200$ mM; Tris- $\mathrm{HCl} 100$ $\mathrm{mM} \mathrm{pH} \mathrm{8.5,} \mathrm{EDTA} 5 \mathrm{mM}$, SDS a $0.2 \%$, proteinase $\mathrm{K} 100 \mu \mathrm{g} / \mu \mathrm{L}$ ), seguida de incubação por $16 \mathrm{~h}$ (overnight) a $37^{\circ} \mathrm{C}$. O DNA foi clivado passando por uma agulha de $18 \mathrm{G}$ aproximadamente 10 vezes, extraído com fenol-clorofórmio e precipitado com etanol. O DNA genômico total $(10 \mu \mathrm{g})$ foi digerido com BamH I e logo após separado em gel de agarose a $0,8 \%$, denaturado por 45 minutos em $\mathrm{NaCl} 1,5 \mathrm{M}$ e NaOH 0,5 M, e transferido para uma membrana de nylon Hybond-N. A membrana foi pré-hibridizada em solução de hibridização contendo fosfato de sódio $0,5 \mathrm{M} \mathrm{pH} 7,2$, EDTA $1 \mathrm{mM} \mathrm{pH} \mathrm{8,0,} \mathrm{SDS} \mathrm{a} \mathrm{7 \% ,} \mathrm{BSA} \mathrm{a} \mathrm{1 \% .} \mathrm{A} \mathrm{sonda} \mathrm{de} \mathrm{mGH}$ foi a mesma utilizada no Northern blotting e foi marcada com o sistema de 
marcação de DNA Ready-To-Go. A sonda marcada foi purificada com microcolunas Illustra G-25, denaturada, adicionada a uma nova solução de hibridização, incubada com a membrana por $16 \mathrm{~h}$ (overnight) a $65^{\circ} \mathrm{C}$. A membrana foi lavada duas vezes com fosfato de sódio $40 \mathrm{mM} \mathrm{pH}$ 7,2, EDTA $1 \mathrm{mM}$ pH 8,0, SDS a $5 \%$ e BSA a $0,5 \%$ durante 5 minutos a $65^{\circ} \mathrm{C}$ e oito vezes com fosfato de sódio $40 \mathrm{mM} \mathrm{pH} \mathrm{7,2,} \mathrm{EDTA} 1 \mathrm{mM} \mathrm{pH} \mathrm{8,0,} \mathrm{SDS} \mathrm{a} \mathrm{1 \% .} \mathrm{As} \mathrm{membranas}$ foram visualizadas por auto-radiografia.

\subsubsection{Obtenção do epitélio a partir da placa de cultura}

Queratinócitos transduzidos foram semeados em placas de cultura de $10 \mathrm{~cm}$ de diâmetro e cultivados até atingir a confluência. Os epitélios foram retirados das placas de cultura mediante incubação com dispase $(2,5 \mathrm{mg} / \mathrm{mL})$, diluída em meio KGM (Keratinocyte Growth Medium). O epitélio $\left(78 \mathrm{~cm}^{2}\right.$ ) foi deixado então livre em KGM ou envolto num pedaço de gaze parafinada $(2 \times 2$ $\mathrm{cm}$ ), que atua como um suporte de acordo com a técnica clássica de implante de Barrandon e col. (1988). Outra alternativa foi desprender o epitélio mecanicamente utilizando uma espátula. Após estes procedimentos, os epitélios foram incubados por $24 \mathrm{~h}$ em KGM sem soro, o qual foi coletado para a determinação de $\mathrm{mGH}$ por RIA.

\subsubsection{Construção da cultura celular organotípica}

A metodologia de preparo deste tipo de cultura, utilizada por Kolodka e col. (1998), foi posteriormente modificada pelo mesmo grupo de pesquisa. A principal alteração consistiu na introdução de uma primeira camada acelular composta basicamente de colágeno tipo I obtido da cauda de rato. Esta primeira camada acelular foi colocada sobre um inserto de plástico (Anopore ${ }^{\circledR}$ Membrane), acomodado num poço de uma placa de 6 poços, para diminuir a possibilidade da segunda camada se desprender e sofrer um encolhimento. A primeira matriz (camada acelular) foi portanto composta de meio de cultura DMEM (Dulbecco's Modified Eagle's Medium), soro fetal bovino (SFB), $\mathrm{NaOH} 1 \mathrm{M}$ e colágeno. Esta matriz foi então pipetada sobre o inserto e incubada a $37^{\circ} \mathrm{C}$ para polimerizar 
durante aproximadamente $30 \mathrm{~min}$. A segunda matriz (camada celular) foi preparada com os mesmos reagentes adicionando-se $2 \times 10^{5}$ fibroblastos humanos/inserto e a mistura foi pipetada sobre a primeira camada seguida de polimerização por $\sim 1 \mathrm{~h}$ nas mesmas condições. Foram adicionados $2 \mathrm{~mL}$ de KGM sobre as matrizes e $3 \mathrm{~mL}$ na placa de cultura. Seguiu-se uma incubação de 7 dias na estufa a $37^{\circ} \mathrm{C}$ e $5 \% \mathrm{CO}_{2}$ com uma troca de meio após 3 dias, antes da adição dos queratinócitos transduzidos ou não modificados $\left(\begin{array}{llll}7 & \times & 10^{5}\end{array}\right.$ células/inserto) sobre as matrizes. Após 4 dias desta adição, os queratinócitos foram mantidos numa interface ar-líquido, retirando-se o meio KGM e recolocando-se apenas $2 \mathrm{~mL}$ na placa de cultura. Este meio foi trocado a cada 2 dias e as culturas organotípicas estavam prontas para serem implantadas nos camundongos após 10-14 dias.

\subsubsection{Implante da cultura celular organotípica em camundongos anões imunodeficientes (lit/scid)}

Antes do procedimento de implante cirúrgico, os animais de 45-90 dias foram anestesiados com $100 \mu \mathrm{L}$ de uma mistura contendo $2 \mathrm{~mL}$ de cloridrato de quetamina, 0,5 mL de cloridrato de xilazina e $2,5 \mathrm{~mL}$ de solução salina estéril e o pêlo da região escapular dorsal foi retirado. A seguir, a pele do animal (um círculo de $\sim 1,2 \mathrm{~cm}$ de diâmetro) foi retirada para acomodar a cultura organotípica, que foi recoberta com um fragmento de gaze parafinada e curativo com band-aid durante uma ou duas semanas.

Em diferentes intervalos de tempo após o implante, foram coletadas amostras de sangue via plexo retro-orbital para determinação dos níveis circulantes de mGH por RIA. O peso dos animais implantados com queratinócitos transduzidos ou do grupo controle (queratinócitos não modificados), foi monitorado durante 20 semanas para avaliar possíveis alterações no peso corpóreo (Bellini e Bartolini, 1993; Bellini e col., 1998). 


\subsubsection{Inoculação de mGH via subcutânea}

Uma quantidade similar de $\mathrm{mGH}$ à da secretada pela cultura organotípica, ou seja, $2 \mu \mathrm{g}$ deste hormônio obtido do NHPP em $50 \mu \mathrm{L}$ de solução salina, foi administrada subcutaneamente no dorso de camundongos lit/scid (mesma região onde é realizado o implante dos queratinócitos). Em diferentes intervalos de tempo após a inoculação, foram retiradas amostras de sangue para determinação dos níveis circulantes de $\mathrm{mGH}$.

\subsubsection{Cultura dos epitélios retirados após implante}

A cultura celular organotípica foi mantida implantada nos camundongos lit/scid por 7 dias. Os animais foram então sacrificados e os epitélios implantados foram removidos, lavados com PBS e recolocados em cultura com $2 \mathrm{~mL}$ de KGM na forma íntegra ou após recuperação dos queratinócitos com a utilização da tripsina, de acordo com trabalhos que já haviam realizado este tipo de recuperação (Teumer e col., 1990; Kolodka e col., 1998). A quantidade de mGH secretada por estes epitélios ou células recuperadas foi determinada por RIA em meios condicionados de $24 \mathrm{~h}$ e comparada com a da concentração nos meios coletados de culturas organotípicas mantidas in vitro durante o experimento.

\subsubsection{Imunohistoquímica dos epitélios retirados após implante}

Para a imunoshistoquímica, epitélios derivados de culturas organotípicas foram removidos 1 e 7 dias após o implante. Estes epitélios recuperados, juntamente com um controle positivo não implantado e um fragmento de pele de camundongo lit/scid (controle negativo), foram fixados em formol tamponado a $10 \%$ para a próxima etapa de parafinização. Após a desparafinização e re-hidratação, as lâminas foram submersas em tampão citrato $\mathrm{pH}$ 6,0 e a recuperação do antígeno foi realizada por aquecimento sob pressão. A atividade da peroxidase endógena foi bloqueada com peridrol a $3 \%$ e os cortes foram incubados por $16 \mathrm{~h}$ (overnight) com os anticorpos mencionados acima a $4^{\circ}$ C. Os cortes histológicos foram submetidos à reação com os seguintes anticorpos 
primários: anti-involucrina humana produzido em coelho, anti-citoqueratina de alto peso molecular (anticorpo monoclonal anti-citoqueratina humana produzido em camundongo, clone 34ßE12) e anti-mGH produzido em coelho. As expressões da involucrina e da citoqueratina foram detectadas com sistemas EnVision plus, baseados em segundos anticorpos anti-coelho e anti-camundongo conjugados a um polímero marcado com peroxidase, enquanto a expressão de $\mathrm{mGH}$ foi detectada utilizando o sistema SuperPicTure Polymer Detection baseados no mesmo princípio. Todos os cortes foram revelados com diaminobenzidina e contra-corados com eosina - hematoxilina.

\subsubsection{Determinação da porcentagem de células-tronco de queratinócitos transduzidos}

Esta determinação foi realizada de acordo com a metodologia descrita por Kolodka e col. (1998). Os queratinócitos transduzidos foram semeados a baixas densidades ( 500 células/placa de cultura de $10 \mathrm{~cm}$ de diâmetro) com o intuito de obter clones isolados. As colônias com diâmetro de $\sim 5 \mathrm{~mm}$ foram isoladas com cilindros de clonagem e as células derivadas de cada clone foram inicialmente semeadas em uma placa de 24 poços (primeira passagem celular), contendo uma camada de fibroblastos irradiados (feeder layer). Após intervalos de 7-10 dias, com os queratinócitos em semi-confluência $(\sim 80 \%)$, as células derivadas de cada clone foram transferidas sucessivamente para placas de $6 \mathrm{~cm}$ (segunda passagem celular) e de $10 \mathrm{~cm}$ de diâmetro (terceira e quarta passagens celulares), perfazendo um total de 4 passagens. Em cada passagem, o meio de cultura condicionado de $24 \mathrm{~h}$ de cada clone foi coletado para determinação do nível de expressão de mGH por RIA e os queratinócitos foram submetidos à contagem em hemocitômetro (câmara de Neubauer) para o cálculo de produtividade em $\mu \mathrm{g} / 10^{6}$ células/dia. 


\subsubsection{Determinação da meia-vida circulatória $\left(t_{1 / 2}\right)$ do $\mathrm{mGH}$ e do hGH em camundongos anões (lit/lit)}

Os camundongos foram injetados via intravenosa, utilizando a veia caudal, com $1 \mu \mathrm{g}$ de hormônio por animal, em $100 \mu \mathrm{L}$ de solução salina. Após as injeções, os animais foram submetidos à sangria via plexo retro-orbital em diferentes tempos ( $\mathrm{n}=4$ animais /tempo). Os níveis circulantes de $\mathrm{hGH}$ e de $\mathrm{mGH}$ no soro foram dosados por RIA e a meia-vida circulatória foi calculada mediante verificação do tempo necessário para que a concentração de hormônio na circulação decaísse à metade do valor máximo alcançado.

\subsubsection{Análise estatística}

As análises para avaliar significância foram realizadas de acordo com 0 teste " $\mathrm{t}$ " de Student, onde $\mathrm{P}<0,05$ foi considerado uma diferença estatisticamente significativa. 


\section{RESULTADOS}

\subsection{Secreção de mGH in vitro por queratinócitos transduzidos}

\subsubsection{Funcionamento de culturas organotípicas}

A partir dos queratinócitos transduzidos com o gene do $\mathrm{mGH}$, que apresentaram altos níveis de secreção in vitro de até $\sim 11 \mu \mathrm{g} \mathrm{mGH} / 10^{6}$ células/dia, foi realizado um experimento no qual estas células foram submetidas à ação da enzima dispase para desprender o epitélio formado in vitro, segundo a metodologia clássica de Barrandon e col. (1988). Como pode ser observado na Tabela 2, epitélios submetidos à ação da dispase ou desprendidos mecanicamente com a utilização de uma espátula, apresentaram uma perda de secreção in vitro $>80 \%$. É interessante observar também que a simples eliminação da dispase mediante desprendimento mecânico, proporcionou um aumento da secreção de $\sim 20 \%$.

Tabela 2: Perda de secreção de $\mathrm{mGH}$ in vitro por queratinócitos transduzidos com o gene deste hormônio, após aplicação de diferentes métodos para desprender os epitélios das placas de cultura

\begin{tabular}{|l|c|c|}
\hline Método para desprender & $\begin{array}{c}\text { Secreção celular } \\
\text { específica de } \mathbf{~ G H} \\
\left(\mu \mathbf{g} / \mathbf{1 0}^{\mathbf{6}} \text { células/dia) }\right.\end{array}$ & $\begin{array}{c}\text { Perda de secreção } \\
\text { (\%) }\end{array}$ \\
\hline a) controle (sem desprender) & 6,50 & 0 \\
\hline b) dispase com gaze parafinada & 0,06 & 99,0 \\
\hline c) dispase sem gaze parafinada & 0,09 & 98,5 \\
\hline d) mecânico (espátula) & 1,25 & 80,8 \\
\hline
\end{tabular}

Foi então comparada a taxa de secreção in vitro de epitélios preparados de acordo com esta técnica clássica, utilizada em nosso laboratório, com aquela obtida utilizando culturas organotípicas preparadas de acordo com Kolodka e col. 
(1998). Com a utilização destas culturas, foi observado que não havia perda de secreção in vitro, enquanto que os epitélios tratados com dispase apresentaram novamente quase $100 \%$ de perda (Fig. 2). Deve-se observar, entretanto, que com as culturas organotípicas houve um aumento da taxa de secreção de $\sim 2$ vezes quando calculada com base no número inicial de queratinócitos utilizados $\left(7 \times 10^{5}\right.$ células/enxerto). Porém, não é possível calcular o número exato de queratinócitos durante a progressão do experimento, devido à complexa mistura de colágeno, fibroblastos e queratinócitos que formam estas culturas. Apesar de haver portanto uma super-estimação da taxa de secreção, acreditamos que este fato não invalide as conclusões do experimento. Outro aspecto a ser considerado é que o tratamento com tripsina e subcultura não influenciou a taxa de secreção do hormônio. Esta taxa foi recuperada após 6 dias da transferência das células para uma segunda placa de cultura preparada com fibroblastos irradiados (feeder layer), onde os queratinócitos se aderiram novamente e se proliferaram, o que não ocorreu após o tratamento com dispase.

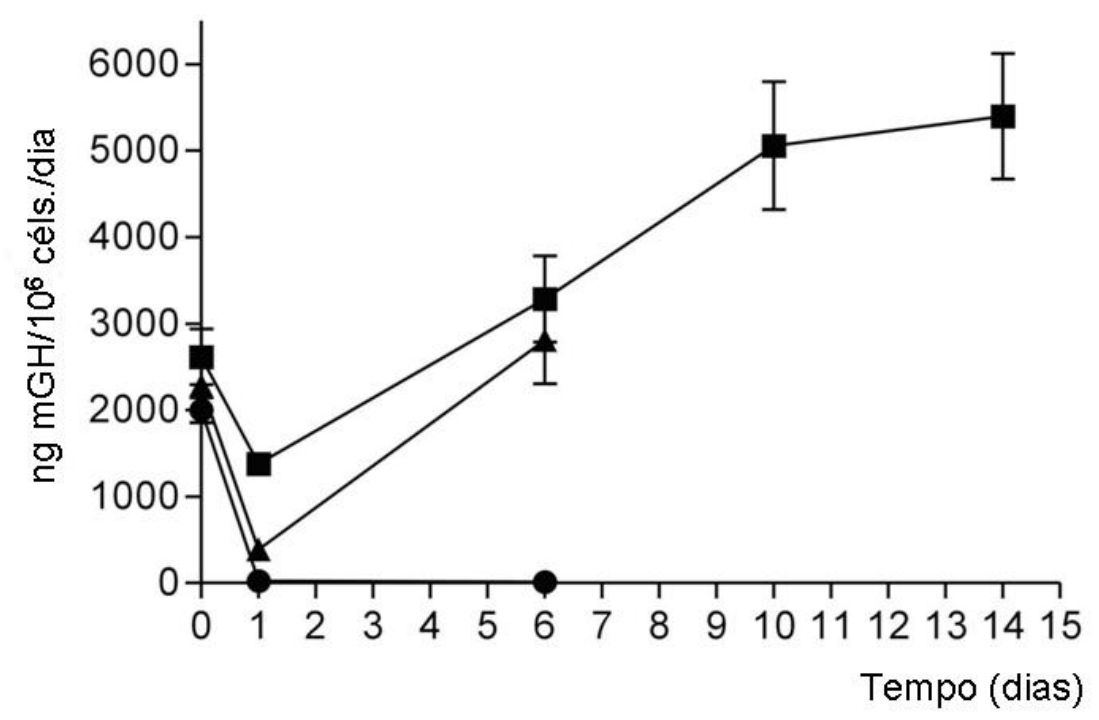

Fig. 2: Secreção in vitro de $\mathrm{mGH}$ por queratinócitos transduzidos, após diferentes tratamentos.

- - epitélio desprendido da placa de cultura mediante tratamento com dispase e transferido para uma segunda placa de cultura também preparada com fibroblastos (feeder layer) $(\mathrm{n}=2)$;

- _ células submetidas a tratamento com tripsina e transferidas como no item anterior, $(n=2)$;

- culturas organotípicas preparadas de acordo com a metodologia de Kolodka e col. (1998) $(n=5)$. 


\subsubsection{Análise clonal}

Um outro estudo realizado com os queratinócitos in vitro foi a determinação da porcentagem de células-tronco transduzidas com mGH. Para esta determinação foram isolados 24 clones de queratinócitos transduzidos e as células derivadas de cada clone foram expandidas durante quatro passagens sucessivas e submetidas à contagem em cada passagem, enquanto os meios condicionados de $24 \mathrm{~h}$ foram coletados e o conteúdo de $\mathrm{mGH}$ determinado por RIA. Verificou-se que após estas passagens (equivalentes a mais que 30 duplicações ou $10^{7}$ células), a maioria dos clones manteve e alguns apresentaram até mesmo um aumento do nível de expresão de mGH (Fig. 3). Estes resultados indicaram portanto que pelo menos $30 \%$ dos clones ( 7 dos 24 ) parece ser derivado de células-tronco transduzidas, pois apresentaram a manutenção de altos níveis de expressão (acima de $10 \mu \mathrm{g} \mathrm{mGH} \mathrm{/} 10^{6}$ células / dia) após as passagens celulares.

Esta porcentagem representaria, de acordo com a literatura a fração de células-tronco transduzidas, sendo que em experimentos anteriores, nos quais os queratinócitos foram submetidos a três passagens celulares, os resultados foram similares.

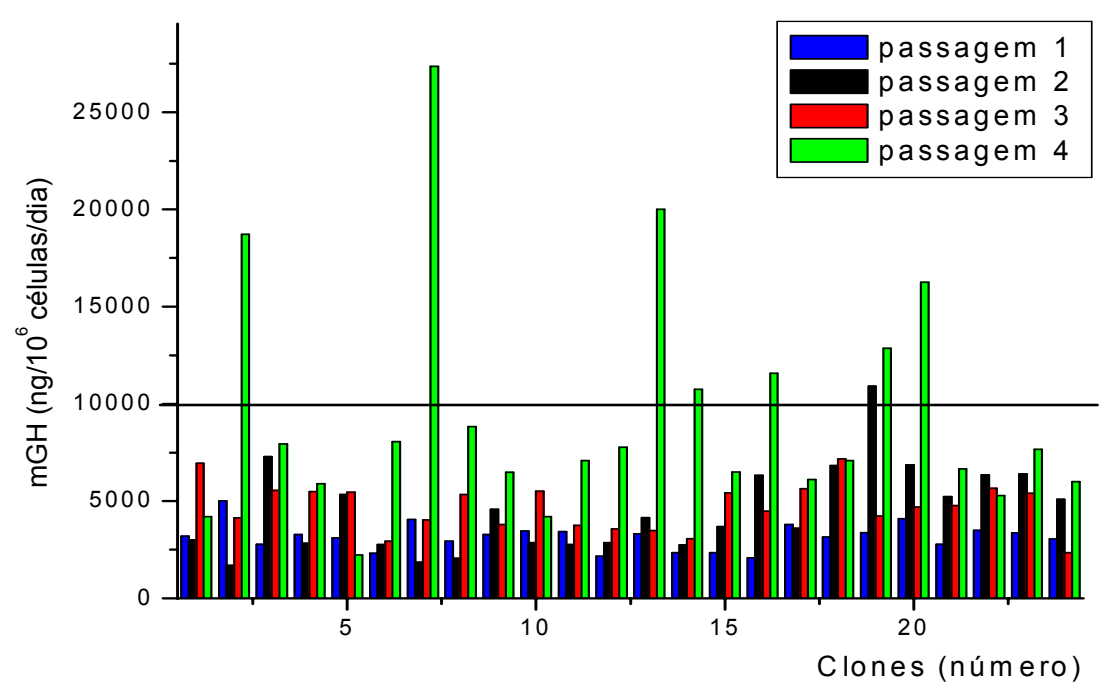

Fig. 3: Níveis de mGH determinados por RIA no meio de cultura de células isoladas (clones) de uma população de queratinócitos transduzidos. As células foram semeadas em placa de 24 poços (passagem 1), transferidas para placas de $6 \mathrm{~cm}$ de diâmetro (passagem 2) e posteriormente para placas de $10 \mathrm{~cm}$ de diâmetro (passagens 3 e 4). As placas foram previamente preparadas com uma camada de fibroblastos irradiados (feeder layer). 


\subsubsection{Análise mediante Northern blotting}

Foi também realizada uma análise por Northern blot, a fim de verificar a presença de mRNA de $\mathrm{mGH}$ nas células utilizadas para a construção da cultura organotípica. Como é mostrado na Fig. 4, os queratinócitos transduzidos apresentaram claramente a presença do mRNA correspondente ao $\mathrm{mGH}$.

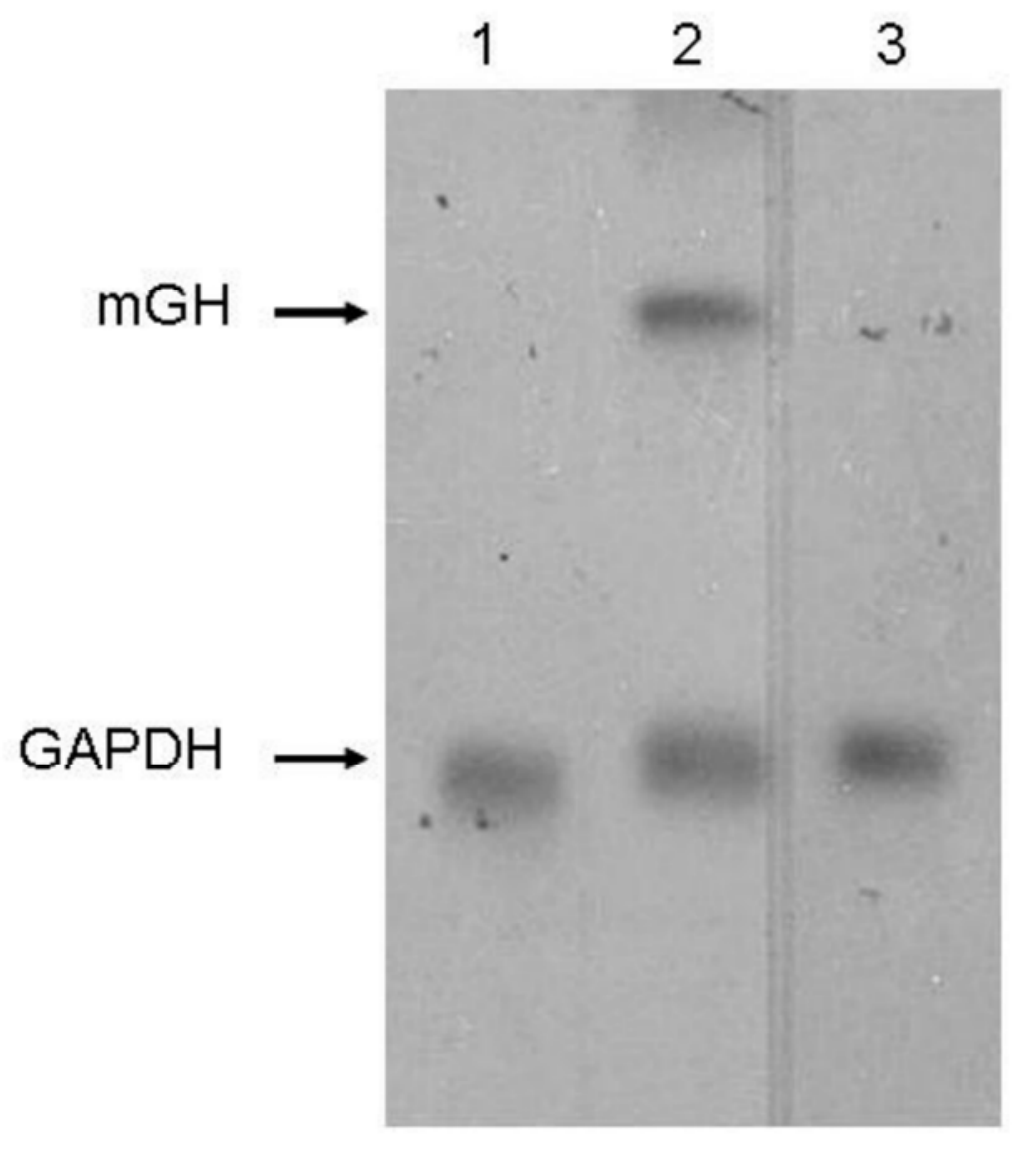

Fig. 4: Northern blotting utilizando um fragmento de cDNA de mGH como sonda. (1) Queratinócitos humanos primários não-transduzidos. (2) Queratinócitos humanos primários transduzidos com o gene do $\mathrm{mGH}$. (3) Fibroblastos imortalizados de camundongo - NIH-3T3J2. GAPDH: sinal correspondente ao cDNA da GAPDH (Glyceraldehyde - 3 - Phosphate Dehydrogenase) humana, utilizado como controle da quantidade de mRNA aplicada no gel. 


\subsection{Secreção de $\mathrm{mGH}$ in vivo por queratinócitos transduzidos}

\subsubsection{Ensaio de longa duração}

As culturas organotípicas foram preparadas para serem implantadas nos camundongos anões imunodeficientes (lit/scid). Um ensaio de longa duração foi realizado utilizando dois grupos de camundongos lit/scid, enxertados com culturas organotípicas contendo queratinócitos transduzidos ou não transduzidos (grupo controle). Os animais foram submetidos à pesagem a cada 2-3 dias durante 4 meses, mas a variação de peso foi significativamente diferente entre os dois grupos $(P<0.05)$ apenas durante 40 dias após o implante. Neste período foi obtida uma inclinação de 0,042 g/animal/dia para os animais implantados com os queratinócitos transduzidos e 0,016 g/animal/dia para o grupo controle. A variação de peso dos camundongos lit/scid nos dois grupos durante o período total do experimento pode ser visualizada na Fig. 5. Entretanto, os enxertos estavam perfeitamente integrados à epiderme e não demonstraram nenhum sinal de rejeição até o $125^{\circ}$ dia.

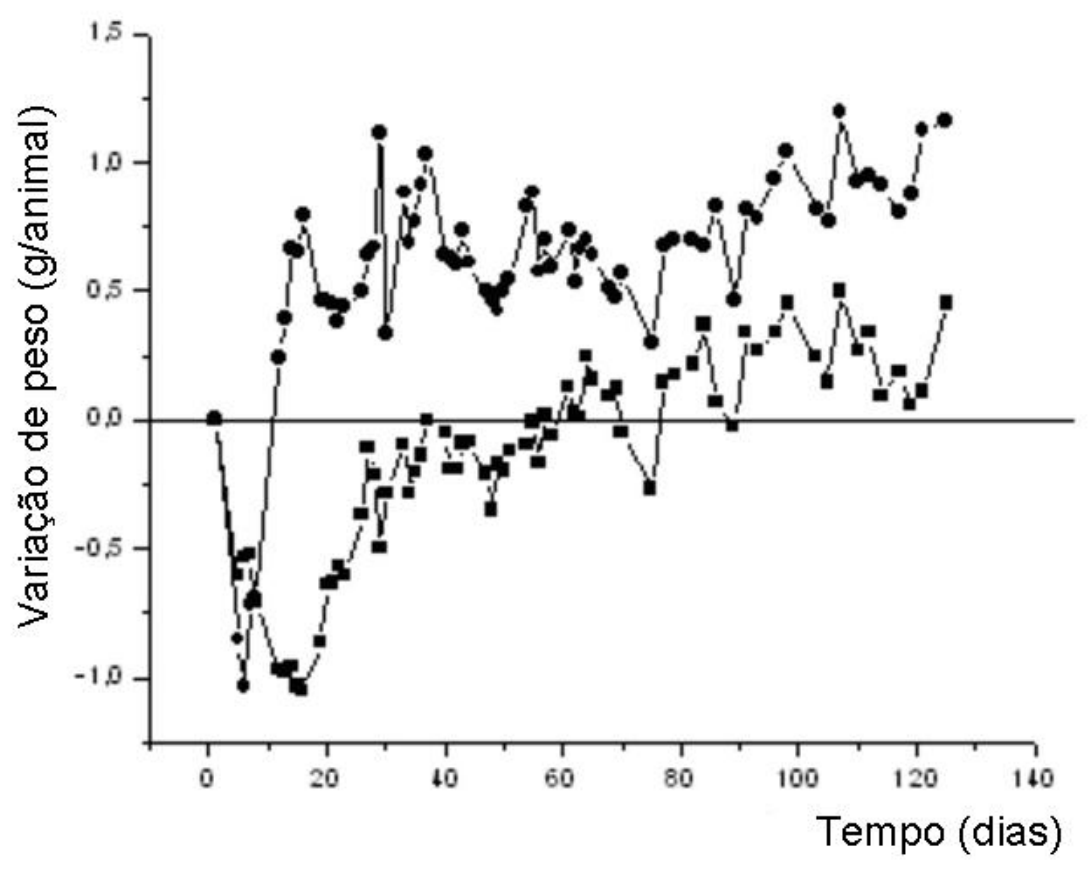

Fig. 5: Variação de peso de camundongos anões imunodeficientes (lit/scid) ( $n=6$ animais/grupo), que receberam implante de queratinócitos transduzidos com o gene do $\mathrm{mGH}(-\bullet-)$ ou de queratinócitos não modificados (- -). Os implantes foram preparados de acordo com uma metodologia de cultura organotípica descrita por Kolodka e col. (1998), posteriormente modificada. As culturas foram implantadas na região dorsal dos animais após retirada do pêlo, segundo técnica descrita pelos mesmos autores. 
Neste mesmo experimento, a determinação dos níveis circulantes de $\mathrm{mGH}$ resultou num valor de $\sim 4 \mathrm{ng} / \mathrm{mL}$ após $4 \mathrm{~h}$ do implante, esses níveis logo decaíram e 4 dias depois haviam se igualado aos valores basais (Fig. 6).

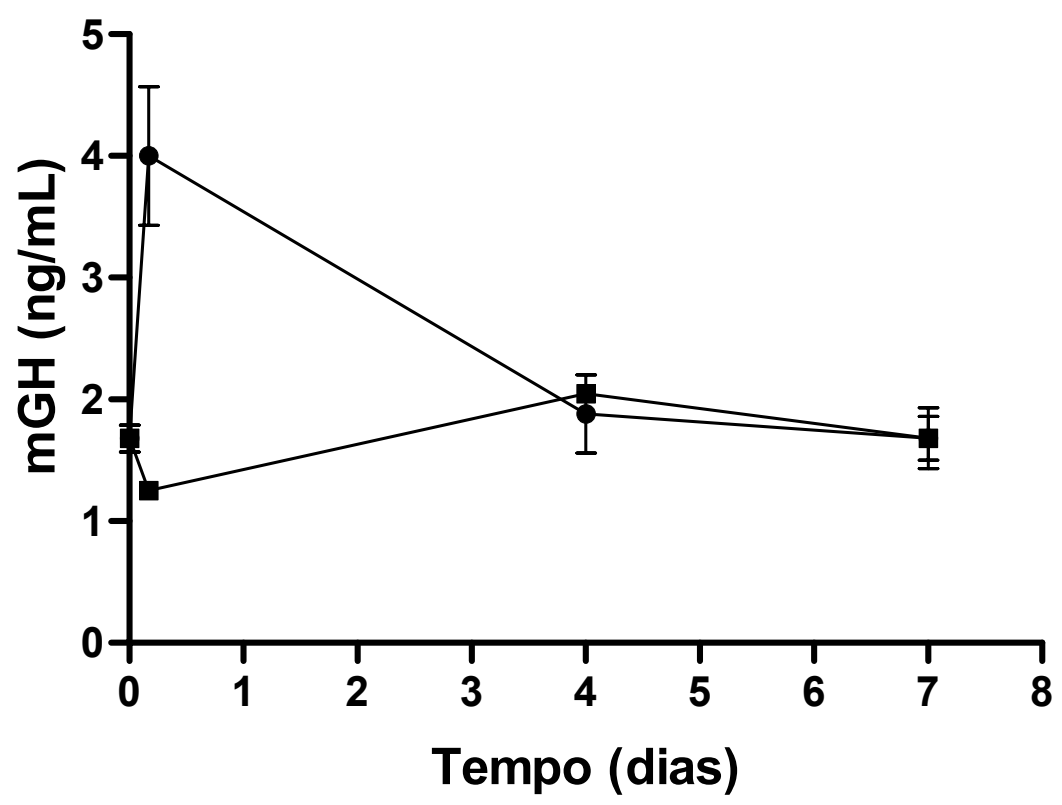

Fig. 6: Níveis de $\mathrm{mGH}$ circulante em camundongos lit/scid ( $\mathrm{n}=2$ animais/ponto), que receberam implante de queratinócitos transduzidos com o gene do $\mathrm{mGH}(-\bullet-)$ ou de queratinócitos não modificados (- - Os implantes foram preparados como descrito na legenda da Fig.5. São apresentados os valores médios e os desvios padrões da média.

\subsubsection{Estudo da dinâmica de secreção in vivo}

Uma análise mais detalhada foi então realizada para se tentar compreender a dinâmica da secreção in vivo do $\mathrm{mGH}$ imediatamente após o enxerto da cultura organotípica, realizando coletas de sangue dos animais implantados em intervalos menores de tempo, num período de $24 \mathrm{~h}$. Os resultados apresentados na Fig. 7 evidenciam um pico de secreção relativamente elevado ( $20 \mathrm{ng} \mathrm{mGH} / \mathrm{mL}$ ) na circulação dos camundongos após $1 \mathrm{~h}$ da cirurgia, níveis estes que se mantiveram apenas $24 \mathrm{~h}$, quando se igualaram aos valores basais do grupo controle.

Deve ser enfatizado também que as culturas organotípicas foram lavadas 3 vezes com meio de cultura, a fim de diminuir a possibilidade de transferência passiva de hormônio sintetizado in vitro. Estes enxertos exibiram 
imediatamente antes da cirurgia, uma secreção in vitro de 1,89 $\pm 0,57 \mu \mathrm{g} \mathrm{mGH/dia}$ $(n=5)$.

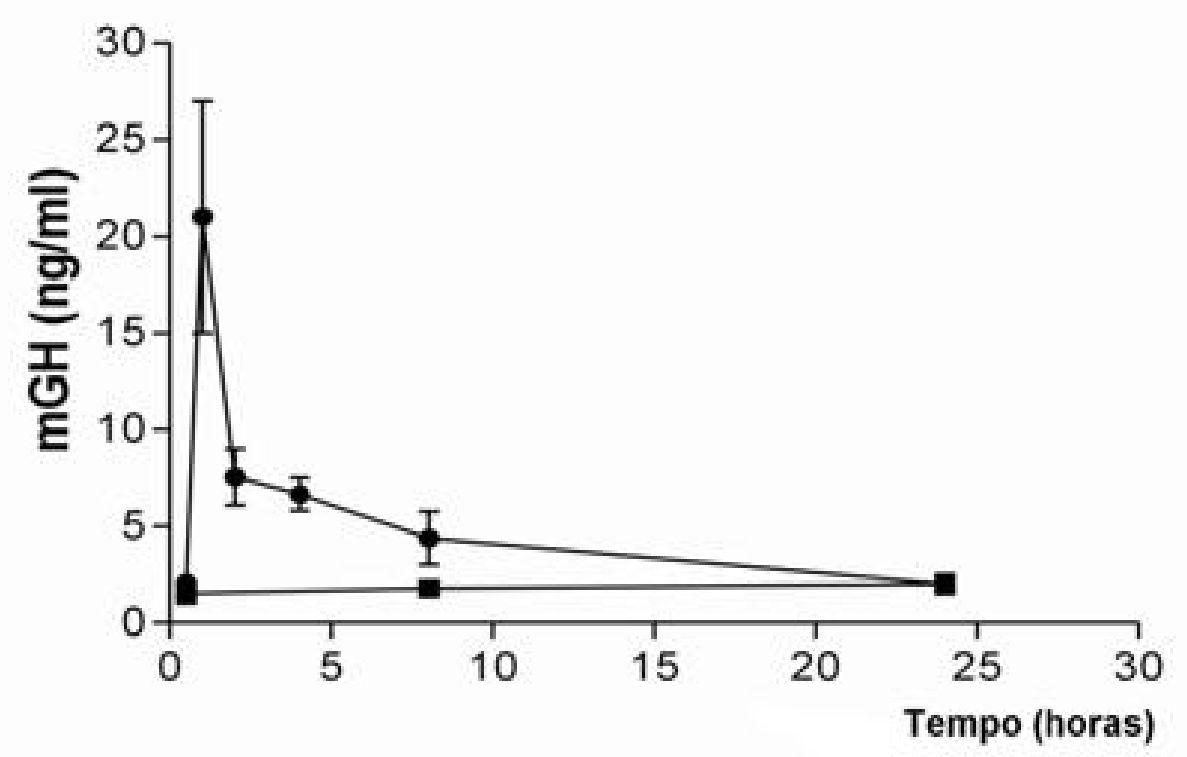

Fig. 7: Níveis de $\mathrm{mGH}$ circulante em camundongos lit/scid ( $\mathrm{n}=2$ animais/ponto), que receberam implante de queratinócitos transduzidos com o gene do $\mathrm{mGH}(-\bullet-)$ ou de queratinócitos não modificados (- - ) O preparo da cultura organotípica e o implante foram realizados como descrito na legenda da Fig. 5. São apresentados os valores médios e os desvio padrão da média.

\subsubsection{Comparação entre enxertos organotípicos e administração subcutânea de $\mathrm{mGH}$}

Os níveis circulantes de mGH obtidos após o implante destes enxertos foram então comparados com os níveis obtidos na circulação dos animais após administração subcutânea de $2 \mu \mathrm{g}$ do mesmo hormônio (Fig. 8). Deve-se levar em consideração que na administração subcutânea ocorre um único estímulo seguido da depuração metabólica do hormônio, enquanto que no implante organotípico deveria ocorrer uma secreção mais prolongada. É possível observar que os níveis circulantes obtidos foram similares nos dois procedimentos, mas há uma diferença de $\sim 50 \mathrm{~min}$ para que $\circ \mathrm{mGH}$ secretado pelos implantes atinja os mesmos níveis daqueles obtidos com a injeção. Pode-se observar também que com a administração subcutânea a quantidade de $\mathrm{mGH}$ circulante é claramente maior e sua presença mais extensa. 


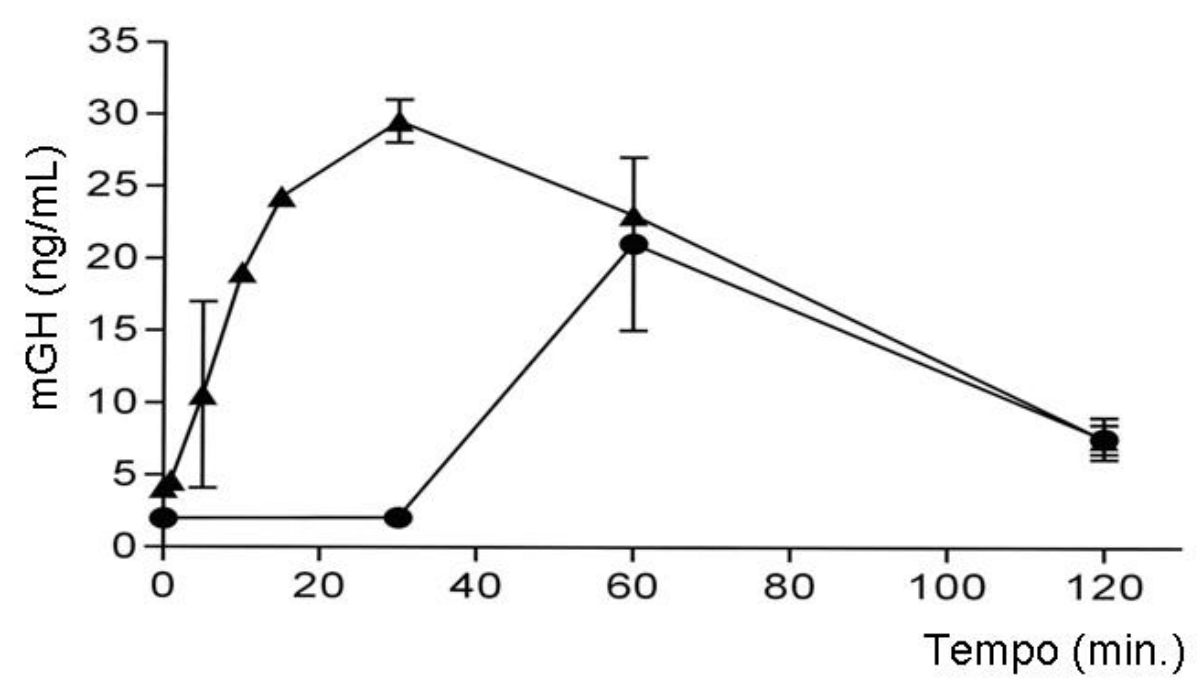

Fig. 8: Níveis de $\mathrm{mGH}$ no soro de camundongos lit/scid ( $\mathrm{n}=2$ animais/ponto), que receberam implante de queratinócitos humanos transduzidos com o gene do $\mathrm{mGH}$ $(-\bullet$ ) ou que foram injetados via subcutânea com $2 \mu \mathrm{g}$ de $\mathrm{mGH}(-$ - . São apresentados os valores médios e o desvio padrão da média.

\subsubsection{Retirada dos enxertos após uma semana de implante}

Foi também verificado que culturas organotípicas retiradas após 1 semana do implante, apresentaram uma secreção de $191 \pm 84 \mathrm{ng}$ $\mathrm{mGH} / \mathrm{implante} / \mathrm{dia}$, o que representa $\sim 45 \%$ do valor de $424 \pm 271 \mathrm{ng}$ $\mathrm{mGH} /$ implante/dia obtido para culturas mantidas in vitro durante o mesmo período de tempo (Tabela 3). Pode-se observar que mesmo as células recuperadas com tripsina, apesar de uma redução maior da secreção de $\mathrm{mGH}$, não apresentaram uma completa supressão da secreção deste hormônio.

Tabela 3: Níveis de $\mathrm{mGH}$ determinados em meios condicionados $(24 \mathrm{~h})$ de culturas organotípicas, mantidas in vitro ou recuperadas de camundongos lit/scid implantados

\begin{tabular}{|c|c|c|}
\hline $\begin{array}{c}\text { Condições da cultura } \\
\text { organotípica }\end{array}$ & ng $\mathbf{~ G H} / \mathbf{m L}^{\mathbf{a}}$ & $\mathbf{n g ~}^{\mathbf{m G H}} /$ implante $^{\mathbf{a}}$ \\
\hline in vitro & $212 \pm 135$ & $424 \pm 271$ \\
\hline implantada e retirada & $95,6 \pm 41,7$ & $191 \pm 84$ \\
\hline in vitro + tripsina & $170 \pm 31,2$ & $340 \pm 62$ \\
\hline $\begin{array}{c}\text { implantada e retirada }+ \\
\text { tripsina }\end{array}$ & $43,5 \pm 38,1$ & $89 \pm 15,6$ \\
\hline
\end{tabular}

a Secreção de $\mathrm{mGH}$ média \pm SD; cada valor é derivado de $\mathrm{n}=3$ placas de cultura. 


\subsubsection{Análise imunohistoquímica dos enxertos}

A persistência de células humanas in vivo foi confirmada por imunohistoquímica, utilizando anticorpos anti-involucrina humana e anticitoqueratina humana de alto peso molecular, como ilustrado na Fig. 9. É interessante observar que, após 1 semana as células humanas aparentemente migraram para a camada de colágeno, a qual parece desprovida de vascularização.

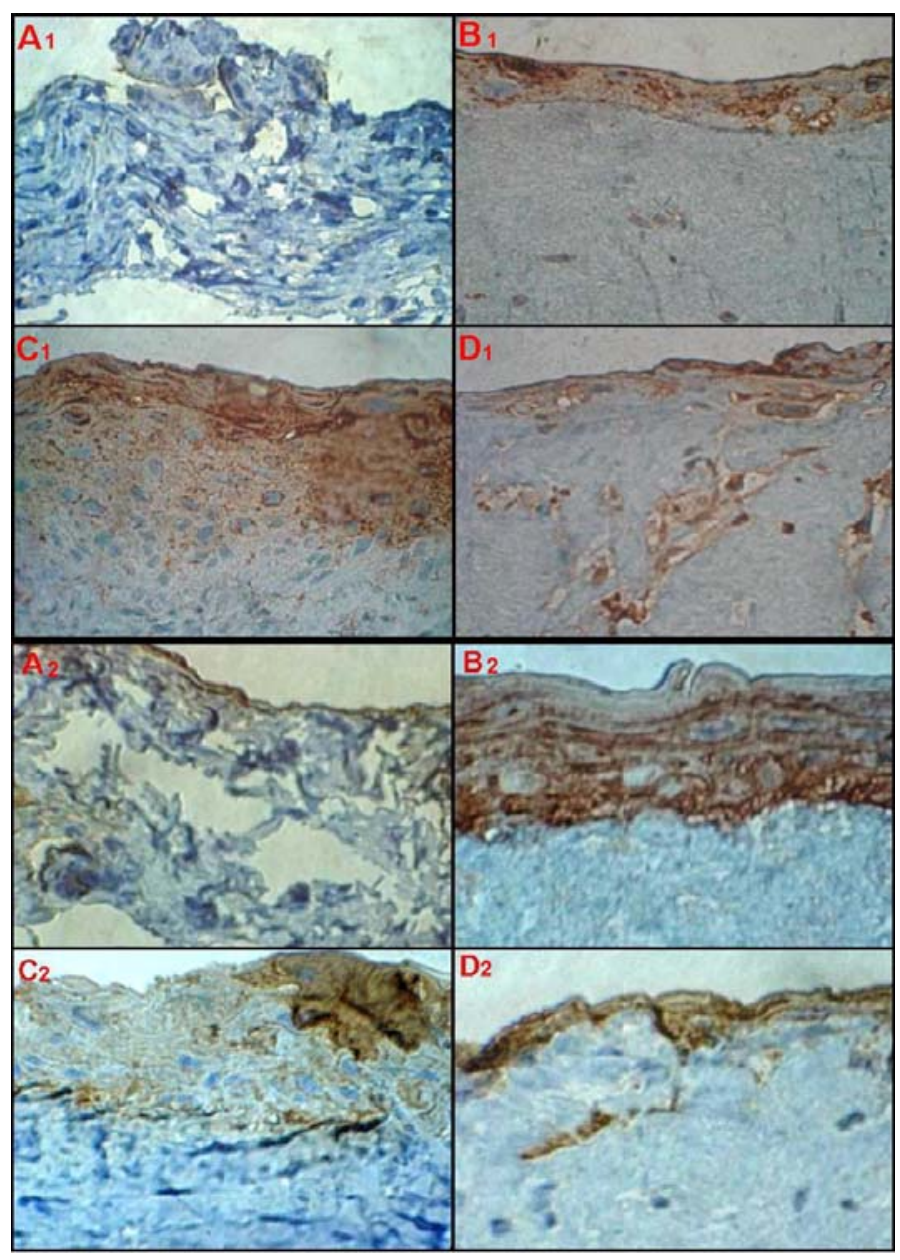

Fig. 9: Imunohistoquímica utilizando anticorpos anti-involucrina humana (A1-D1) e anti-citoqueratina humana de alto peso molecular (A2-D2). (A) Fragmento de pele de camundongo lit/scid. (B) Cultura organotípica mantida in vitro (não implantada). (C) Implante retirado 1 dia após cirurgia. (D) Implante retirado 7 dias após cirurgia. (A-D, $x$ 100). 
Foi realizada uma análise confirmatória também por imunohistoquímica, específica para verificar a presença de hormônio de crescimento de camundongo no epitélio humano implantado no animal, utilizando anticorpo anti-mGH. Podemos observar na Fig. 10, a presença de células secretoras desta proteína, após 1 e 7 dias, do implante.

$\mathrm{Na}$ cultura organotípica não implantada (amostra B) e no implante retirado 1 dia após a cirurgia (amostra $\mathrm{C}$ ), os queratinócitos secretores de mGH encontram-se mais estratificados no topo, enquanto 7 dias após o implante (amostra D), estas células ainda estão presentes, porém mais dispersas dentro do epitélio.

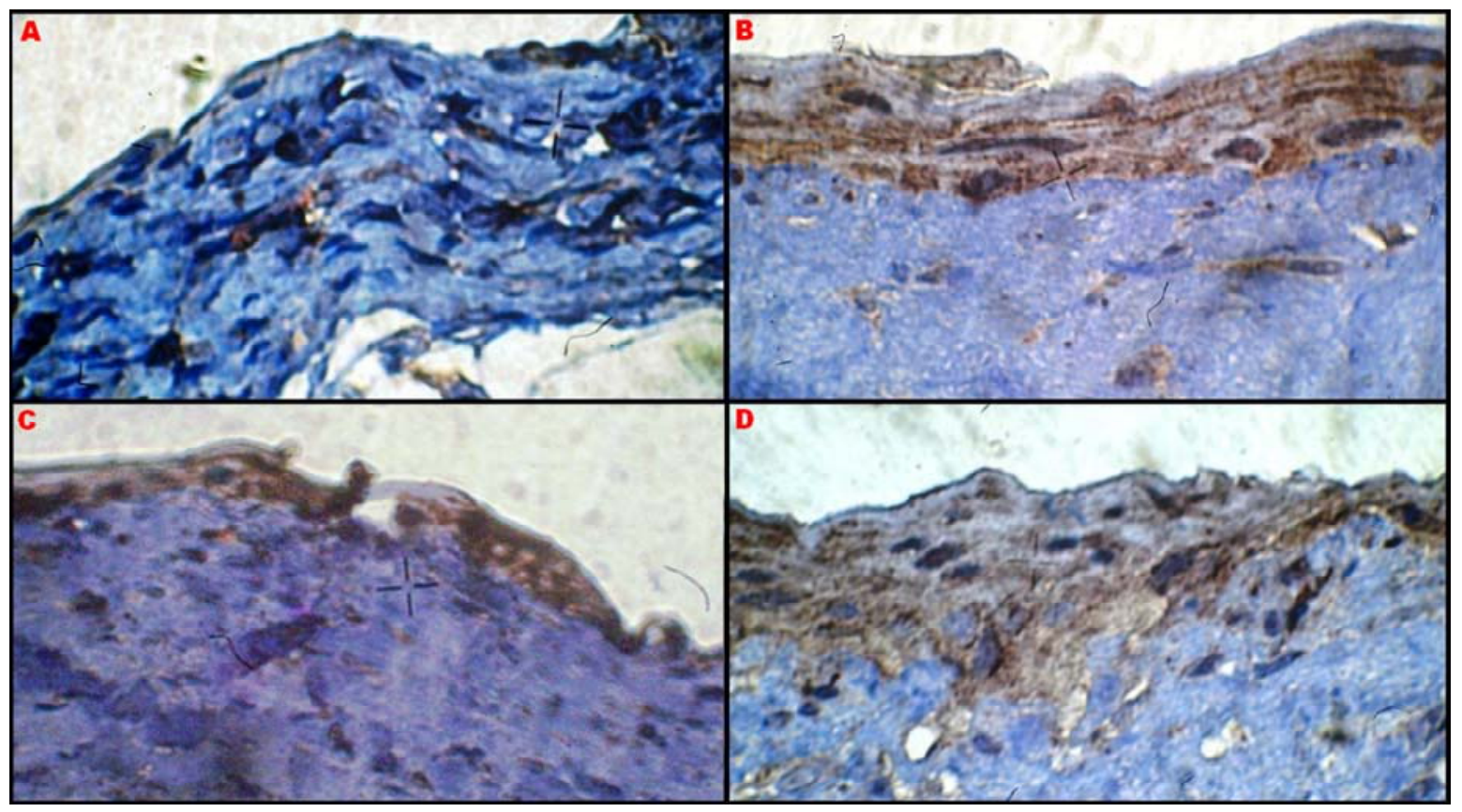

Fig. 10: Imunohistoquímica utilizando anticorpo anti-mGH. (A) Fragmento de pele de camundongo lit/scid. (B) Cultura organotípica mantida in vitro (não implantada). (C) Implante retirado um dia após a cirurgia. (D) Implante retirado uma semana após a cirurgia. (A-D, x 100).

\subsubsection{Análise por Southern blot}

Para verificar a presença do cDNA do $\mathrm{mGH}$ nos queratinócitos implantados, foi realizada uma análise por Southern blot, utilizando um fragmento do cDNA do $\mathrm{mGH}$ como sonda. Foram analisadas amostras sem implantar e 1 e 7 dias após o implante. Na Fig. 10 podemos observar o sinal 
devido à presença do cDNA da proteína de interesse nos queratinócitos transduzidos, mesmo após 7 dias do implante. Como esperado, nenhum sinal pode ser visualizado nos implantes com queratinócitos não transduzidos.

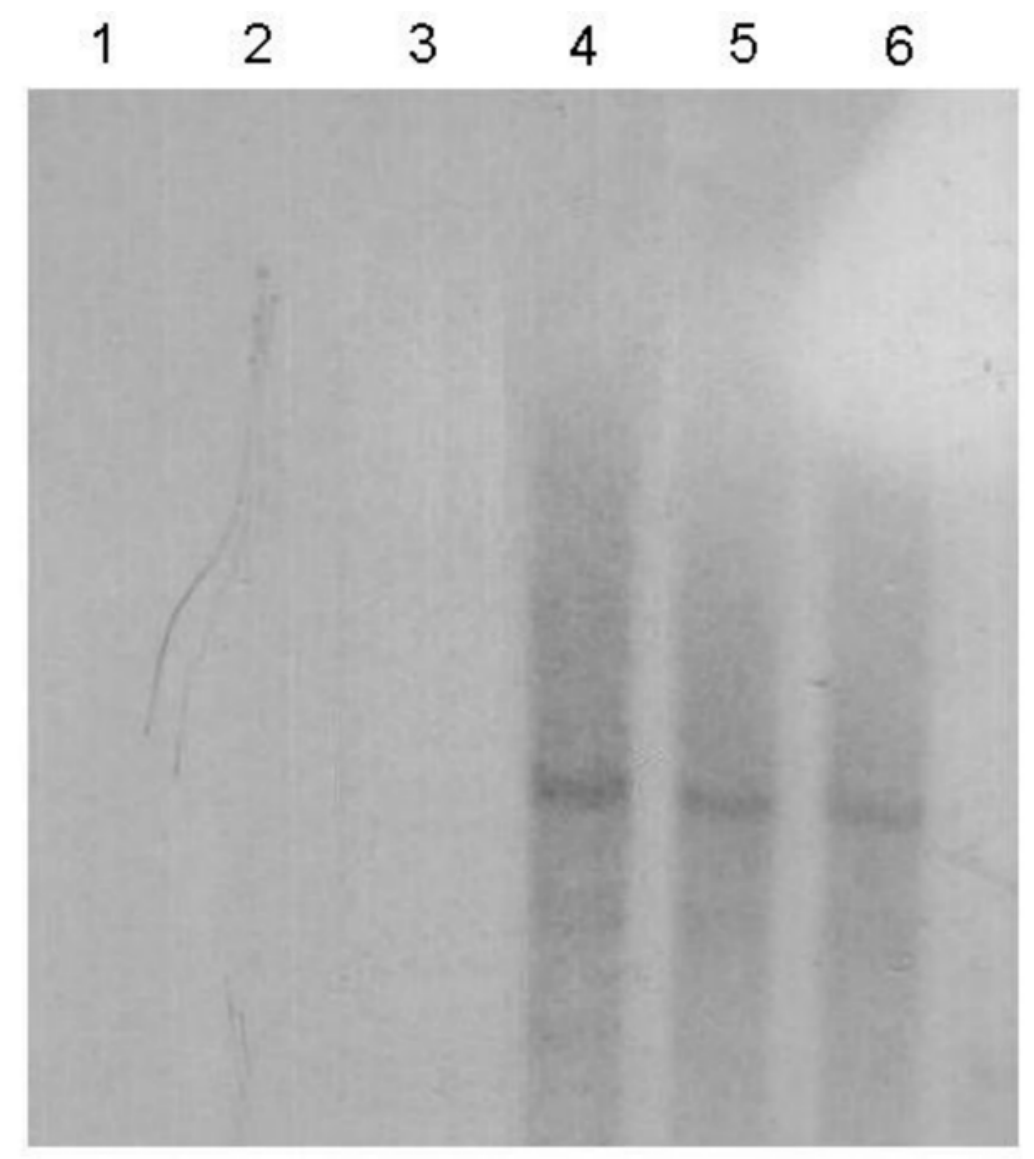

Fig. 10: Análise por Southern blot utilizando um fragmento de cDNA de mGH como sonda. Queratinócitos não transduzidos obtidos de (1) cultura organotípica antes do implante, (2) cultura organotípica retirada 1 dia após o implante, (3) cultura organotípica retirada 7 dias após o implante. Queratinócitos secretores de $\mathrm{mGH}$ obtidos de (4) cultura organotípica antes do implante, (5) cultura organotípica retirada 1 dia após o implante, (6) cultura organotípica retirada 7 dias após o implante.

\subsection{Determinação da meia-vida circulatória $\left(t_{1 / 2}\right)$ do $\mathrm{mGH}$ e do $\mathrm{hGH}$ em camundongos anões (lit/lit)}

A meia-vida circulatória $\left(\mathrm{t}_{1 / 2}\right)$ do $\mathrm{mGH}$ e do $\mathrm{hGH}$ foi determinada injetandose estes hormônios em camundongos anões (lit/lit), via intravenosa (veia caudal), e verificando-se a variação dos níveis circulantes de cada hormônio com o tempo. Um exemplo das curvas obtidas nos ensaios com mGH é apresentado na Fig. 11, onde foi obtido um $t_{1 / 2}=55,5 \pm 19,1 \min (n=3)$ para este hormônio. Porém não 
houve uma diferença estatisticamente significativa $(P=0,24)$ entre o $t_{1 / 2}$ obtido para o $\mathrm{mGH}$ e aquele calculado para $\circ \mathrm{hGH}\left(\mathrm{t}_{1 / 2}=39,5 \pm 2,1 \mathrm{~min} ; \mathrm{n}=2\right)$ em experimentos anteriores. Estes resultados indicaram portanto que a utilização do $\mathrm{mGH}$ em camundongo provavelmente não é um fator determinante para a manutenção dos níveis circulatórios, quando comparado com a utilização do hGH no nosso modelo de terapia gênica cutânea.

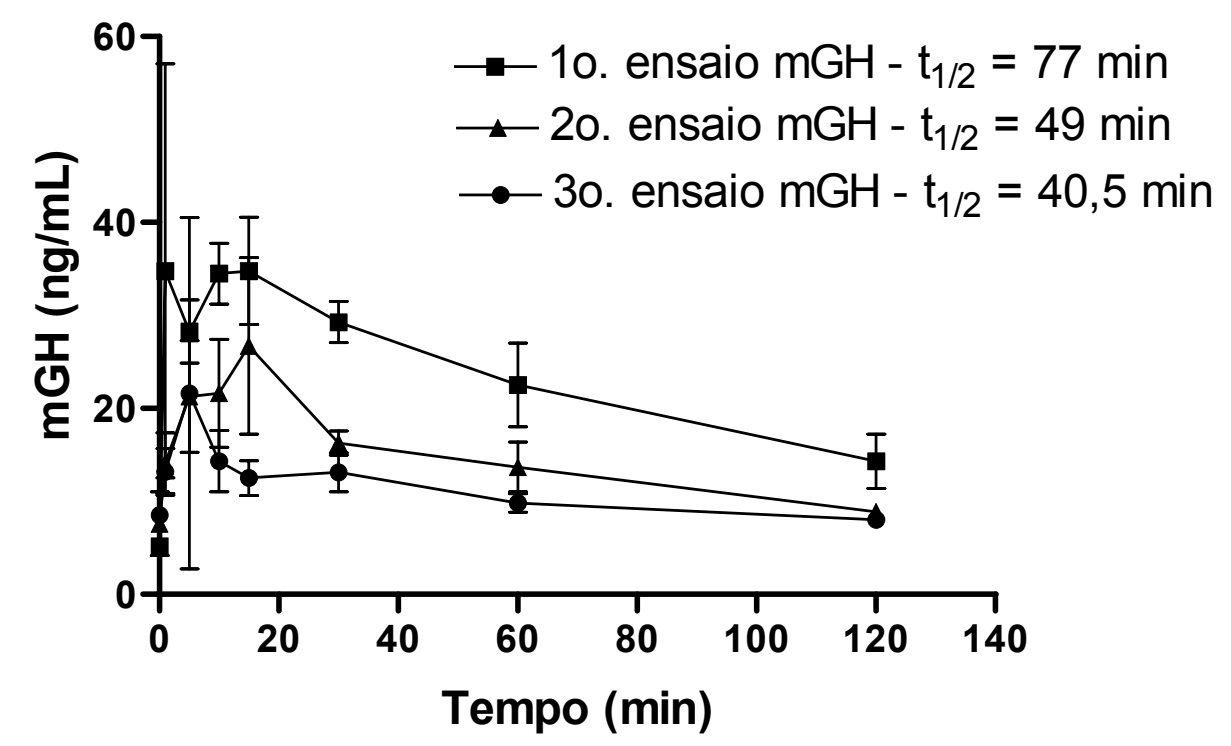

Fig. 11: Níveis de $\mathrm{mGH}$ circulante em camundongos lit/lit ( $\mathrm{n}=4$ animais/ponto), injetados via intravenosa com $1 \mu \mathrm{g}$ de $\mathrm{mGH}$ e submetidos à sangria em diferentes tempos. São mostrados os valores de meia-vida circulatória ( $\left.t_{1 / 2}\right)$ obtidos em três ensaios. Cada ponto representa o valor médio e o desvio padrão da média. 


\section{DISCUSSÃO}

Neste trabalho foi utilizada uma metodologia de cultura celular organotípica (Garlick e Taichman, 1994; Kolodka e col., 1998) para implantar em camundongos lit/scid os queratinócitos transduzidos com o gene do $\mathrm{mGH}$, que apresentaram os mais altos níveis de expressão in vitro já descritos na literatura, atingindo $11 \mu \mathrm{g}$ $\mathrm{mGH} / 10^{6}$ células/dia (Rosauro, 2003; Peroni e col., 2006; Peroni e col., 2008). A alteração do sistema de implante foi realizada após verificação de que o epitélio, formado por estes queratinócitos modificados geneticamente, apresentou uma queda de secreção in vitro de $\mathrm{mGH}>80 \%$, quando utilizada a enzima dispase de acordo com procedimento clássico de implante (Barrandon e col., 1988).

Como reportado na literatura, a secreção in vitro de um epitélio desprendido da placa de cultura apresentou uma perda de $72-83 \%$, quando comparada com aquela das células aderidas (Teumer e col., 1990). Um resultado semelhante foi portanto obtido neste trabalho, quando o método clássico de preparação dos epitélios foi utilizado (Barrandon e col., 1988; Bellini e col., 2003). Isto sugere que os queratinócitos teriam capacidade de secreção somente quando se encontram aderidos à uma superfície ou membrana específica. Evitando o uso de dispase (por exemplo, mediante desprendimento mecânico), houve uma recuperação da secreção de $\sim 20 \%$. A utilização da cultura celular organotípica, que é mais similar ao sistema natural (Garlick e Taichman, 1994; Parenteau e col., 1996), demonstrou ser uma alternativa válida, uma vez que houve a manutenção dos altos níveis de expressão de $\mathrm{mGH}$ in vitro, como apresentado na Fig. 2. Este fato demonstra que in vitro, as células transduzidas apresentaram na cultura organotípica um aumento de seu número ou de sua taxa de secreção. Além disso, nesta etapa do trabalho, foi também realizada uma análise por Northern blot, que confirmou a clara presença do mRNA correspondente ao $\mathrm{mGH}$ nos queratinócitos transduzidos. Esta análise complementou uma caracterização preliminar realizada mediante SDS-PAGE seguida de Western blotting e mediante cromatografia de alta eficiência por exclusão molecular (HPSEC) associada a uma determinação por radioimunoensaio (RIA) (Peroni e col., 2008). 
Considerando a resolução deste problema, juntamente com a potencial vantagem de um sistema homólogo, utilizando $\mathrm{mGH}$ ao invés do hGH, esperavase obter um aumento dos níveis circulatórios concomitante com uma secreção mais prolongada desta proteína a longo prazo. Entretanto, exceto por um pico inicial de secreção de $\sim 20 \mathrm{ng} \mathrm{mGH} / \mathrm{mL}$ após $1 \mathrm{~h}$ do implante, a durabilidade da secreção in vivo e o aumento de peso corpóreo não foram melhores que os obtidos em trabalho anterior (Bellini e col., 2003). Os níveis circulatórios igualaram-se aos basais em $24 \mathrm{~h}$ após a cirurgia, enquanto que o ganho de peso foi significativo apenas nos 40 primeiros dias do ensaio. Durante o período em que os animais implantados foram acompanhados (125 dias), observou-se porém que os queratinócitos apresentaram uma perfeita integração e indistinguível reepitelização na forma de epitélios organotípicos.

A parte mais intrigante dos resultados foi portanto a obtenção de um alto nível inicial de hormônio na circulação atingindo $21 \mathrm{ng} \mathrm{mGH} / \mathrm{mL} 1 \mathrm{~h}$ após o implante, seguido de um rápido declínio destes níveis circulatórios. Já havia sido verificado, contudo, que implantes recuperados 1 semana após o implante nos camundongos lit/scid e recultivados in vitro, apresentaram aproximadamente metade do nível de secreção inicial (Peroni e col., 2006). Foi demonstrado também, por imunohistoquímica, a presença de queratinócitos humanos (utilizando os marcadores involucrina e citoqueratina de alto peso molecular humanos) e destas células secretoras de $\mathrm{mGH}$ (utilizando o marcador específico para este hormônio) 7 dias após o implante. Esta persistência foi ainda confirmada mediante análise por Southern blot, no qual foi visualizado o sinal devido à presença do cDNA do $\mathrm{mGH}$.

A rápida perda dos níveis circulatórios de transgenes secretados por queratinócitos humanos primários modificados geneticamente tem sido atribuída na literatura a várias causas. Dentre elas, podemos citar: morte celular (apoptose) ou diferenciação celular, transporte ineficiente da proteína para a circulação, meia-vida circulatória reduzida, ligação a células endoteliais ou mesmo o efeito de uma barreira formada pela membrana basal existente entre a epiderme e a derme (Teumer e col., 1990; Gerrard e col., 1993). Tem sido ainda sugerida que uma rápida inativação do promotor poderia ocorrer em células que expressam componentes retrovirais (sequências LTR - Long Terminal Repeat - e ativadoras), que são mais susceptíveis à apoptose ou ao silenciamento do transgene por 
metilação do promotor (Mulligan, 1993; Fenjves e col., 1994; Choate e Khavari, 1997; Kolodka e col., 1998; Krueguer e col., 1999). A imunogenicidade da proteína transgênica, dos elementos do vetor ou do tipo celular também tem sido considerada como uma possível causa da eliminação das células transduzidas em animais imunocompetentes (Ghazizadeh e col., 2003; Hengge, 2006).

Baseados em dados da literatura, a maioria dos quais referentes ao $\mathrm{hGH}$, apolipoproteína $E$ (apo E) e fator IX utilizados nos trabalhos citados acima, não é fácil explicar a rápida queda de secreção in vivo do nosso transgene (mGH). Como mencionado nos resultados, as culturas organotípicas foram lavadas antes do implante e, mesmo 30 min após o procedimento cirúrgico, os níveis séricos ainda eram basais. Como também demonstrado por Gerrard e col. (1993) que utilizaram o fator IX, os níveis iniciais relativamente altos de secreção in vivo não seriam devidos a uma transferência passiva de $\mathrm{mGH}$ previamente sintetizado em cultura. A injeção subcutânea de aproximadamente a mesma quantidade de mGH secretado em $24 \mathrm{~h}$ pela cultura organotípica, mostrou que o hormônio atinge a circulação cerca de 50 min antes da proteína secretada pelo implante. Este fato também contribui contra a possibilidade de ocorrência de transferência passiva de mGH em nossas condições de implante.

De qualquer maneira, partindo-se de células altamente secretoras in vitro, algo deve ocorrer que rapidamente bloqueia a secreção ou o transporte da proteína de interesse para a circulação. É ainda prematuro especular as causas desta supressão ou bloqueio imediato. De acordo com os nossos resultados, a meia-vida circulatória $\left(\mathrm{t}_{1 / 2}\right)$ do $\mathrm{mGH}$ em camundongos lit/lit não seria um fator determinante para este rápido mecanismo de perda de secreção. Foi encontrado um valor de $\mathrm{t}_{1 / 2}$ de 55,5 min para o $\mathrm{mGH}$ e de $39,5 \mathrm{~min}$ para o hGH (Peroni e col., 2006); o $\mathrm{t}_{1 / 2}$ do hGH em humanos é da ordem de 11-20 min (Li e col., 2001; Klerman e col., 2003; Melmed e Kleinberg, 2003; Bidlingmaier e col., 2004). Um impedimento de transporte devido à pobre vascularização do local de implante da cultura organotípica, a um rápido processo inflamatório ou à formação de uma barreira específica também é possível, especialmente considerando a ausência de níveis circulatórios contrapondo-se à presença de células secretoras de $\mathrm{mGH}$ 7 dias após o implante; contudo, esta barreira teria que ser ativada imediatamente após o transporte inicial de $\mathrm{mGH}$. 
Nossos resultados, que mostram uma considerável recuperação da secreção após a retirada e cultivo do tecido implantado, também colaboram contra a ocorrência de eventos apoptóticos extremamente eficientes. Embora a presença do promotor LTR e de sequências retrovirais, presentes em nossos queratinócitos transduzidos, tem sido considerada responsável pela inativação do transgene, falha do promotor ou mesmo apoptose (Choate e Khavari, 1997; Krueger e col., 1999), outros autores tendem a excluir esta possibilidade (Teumer e col., 1990; Gerrard e col., 1993; Fenjves e col., 1994; Stockschlader e col., 1994; Ghazizadeh e Taichman, 2000). Finalmente, a utilização de mGH em camundongo imunodeficiente deveria, pelo menos em princípio, excluir alguns mecanismos imunogênicos, especialmente aqueles relacionados à natureza do transgene e dos elementos do vetor. Entretanto, ainda é possível haver alguma resposta imune contra os queratinócitos humanos, especialmente considerando a linhagem de camundongos scid utilizada neste trabalho, que espontaneamente poderia desenvolver uma imunorreatividade parcial levando à produção de células B e T em animais de 12 semanas de idade. Este "vazamento" de resposta imune pode ser mais significativo para camundongos oriundos da linhagem BALB/cBy, segundo comunicado do próprio fornecedor (Jax Communication, $\mathrm{n}^{\circ} 2$, May 25 , 2000).

Considerando os nossos resultados preliminares de determinação da porcentagem de células-tronco transduzidas com $\mathrm{mGH}$, foi observado mediante análise clonal que $\sim 30 \%$ dos clones isolados e expandidos mantiveram ou mesmo apresentaram um aumento significativo de expressão de mGH (Peroni e col., 2006). Esta porcentagem representaria portanto a fração de células-tronco de queratinócitos transduzidos, sendo similar à obtida por Kolodka e col. (1998) que mostraram um valor de $21,1-27,8 \%$ de células-tronco de queratinócitos transduzidos com o gene da $\beta$-galactosidase. É interessante observar que estas células puderam ser detectadas em camundongos nude por um período de até 40 semanas após o implante.

Em conclusão, no presente trabalho foi otimizada a utilização de uma cultura celular organotípica, contendo queratinócitos secretores de $\mathrm{mGH}$, para implante em camundongos lit/scid. O fato da secreção de $\mathrm{mGH}$ in vivo não persistir por mais de um dia, levou-nos a estudar possíveis fatores envolvidos neste bloqueio ou supressão de secreção. Acreditamos que outros estudos, tais 
como a utilização comparativa da metodologia de naked DNA associada à eletroporação in vivo (Prud'homme e col. 2006; Ratanamart e Shaw, 2006; Prud'homme e col., 2007), o enriquecimento da população de queratinócitos em células-tronco e modificações na técnica de implante, podem também ajudar na viabilização clínica desta metodologia mediante identificação dos obstáculos que ainda impedem o sucesso deste modelo promissor de terapia gênica cutânea.

Salientamos que a maioria dos resultados aqui apresentados foram inseridos em duas publicações: em Molecular Biotechnology (Peroni e col., 2006) e no Journal of Gene Medicine (Peroni e col. , 2008). 


\section{REFERÊNCIAS BIBLIOGRÁFICAS}

AL-HENDY, A., HORTELANO, G., TANNENBAum, G.S. AND CHANG, P.L. Correction of the growth defect in dwarf mice with nonautologous microencapsulated myoblasts - an alternate approach to somatic gene therapy. Hum. Gene Ther., v. 6, p. 165-175, 1995.

AL-HENDY, A., HORTElano, G., TANnenbaum, G.S. AND CHANG, P.L. Growth retardation - an unexpected outcome from growth hormone gene therapy in normal mice with microencapsulated myoblasts. Hum. Gene Ther., v. 7, p. 6170, 1996.

AMALFITANO, A. Use of multiply deleted adenovirus vectors to probe adenovirus vector performance and toxicities. Curr. Opin. Mol. Ther., v. 5, p. 362-366, 2003.

BARRANDON, Y., LI, V. AND GREEN, H. New techniques for the grafting of cultured human epidermal cells onto athymic animals. J. Invest. Dermatol., v. 91, p. 315-318, 1988.

BELLINI, M.H. AND BARTOLINI, P. In vivo bioassay for the potency determination of human growth hormone in dwarf "little" mice. Endocrinology, v. 132, p. 20512055, 1993.

BELLINI, M.H., MATHOR, M.B., DE LUCA, M., CANCEDDA, R. AND BARTOLINI, $P$. Ultrasensitive in vivo bioassay detects bioactive human growth hormone in transduced primary human keratinocytes. J. Endocrinol. Invest., v. 21, p. 1-6, 1998.

BELLINI, M.H., PERONI, C.N. AND BARTOLINI P. Increases in weight of growth hormone-deficient and immunodeficient (lit/scid) dwarf mice after grafting of hGHsecreting, primary human keratinocytes. FASEB J., v. 17, p. 2322-2324, 2003. 
BETHESDA (Maryland, USA). National Institutes of health. Clinical Trials. Disponível em:

http://www.clinicaltrials.gov/ct2/results/map?term=gene+therapy. Acesso em: 11 jun. 2008.

BIDLINGMAIER, M., WU, Z. AND STRASBURGER, C.J. Problems with GH doping in sports. J. Endocrinol. Invest., v. 26, p. 924-931, 2004.

BLAESE, R.M., CULVER, K.W., MILLER, A.D., CARTER, C.S., FlEISHER, T., CLERICI, M., SHEARER, G., CHANG, L., CHIANG, Y.W., TOLSTOSHEV, P., GREENBLATT, J.J., ROSENBERG, S.A., KLEIN, H., BERGER, M., MULLEN, C.A., RAMSEY, W.J., MUUL, L., MORGAN, R.A., AND ANDERSON, W.F. Tlymphocyte-directed gene therapy for ADA ( ${ }^{-}$) SCID: initial trials results after 4 years. Science, v. 270, p. 475-480, 1995.

BRANSKY, L.B., PEREIRA, C.T., HERNDON, D.N. AND JESCHKE, M.G. Gene therapy in wound healing: present status and future directions. Gene Ther., v. 14, p. 1-10, 2007.

CAVAZZANA-CALVO, M., HACEIN-BEY, S., DE SAINT BASILE, G., GROSS, F., YVON, E., NUSBAUM, P., SElZ, F., HUE, C., CERATIN, S., CASANOVA, J.L., BOUSSO, P., DEIST, F.L., AND FISCHER, A. Gene therapy of human severe combined immunodeficiency (SCID)-X1 disease. Science, v. 288, p. 669-672, 2000.

CHOATE, K.A., AND KHAVARI P.A. Sustainability of keratinocyte gene transfer and cell survival in vivo. Hum. Gene Ther., v. 8, p. 895-901, 1997.

CHURCH, G.M. AND GILBERT, W. Genomic sequencing. Proc. Natl. Acad. Sci. USA, v. 81, p. 1991-1995, 1984.

DEITEL, K., DANTZER, D., FERGUSON, P., POLLACK, M., BEAMER, W., ANDRULIS, I. AND BELL, R. Reduced growth of human sarcoma xenografts in hosts homozygous for the lit mutation. J. Surg. Oncol., v. 81, p. 75-79, 2002. 
DE LUCA, M. AND PELLEGRINI, G. The importance of epidermal stem cells in keratinocyte-mediated gene therapy. Gene Ther; v. 4, p. 381-383, 1997.

DUNNWALD, M., TOMANECK-CHALKLEY, A., ALEXANDRUNAS, D., FISHBAUGH, J. AND BICKENBACH, J.R. Isolating a pure population of epidermal stem cells for use in tissue engineering. Exp. Dermatol., v. 10, p. 45-54, 2001.

EDELSTEIN, M.L., ABEDI, M.R., WIXON, J. AND EDELSTEIN, R.M. Gene therapy clinical trials worlwide 1989-2004 - an overview. J. Gene Med., v. 6, p. 597-602, 2004.

FENJVES, E.S., SMITH, J., ZARADIC, S. AND TAICHMAN, L.B. Systemic delivery of secreted protein by grafts of epidermal keratinocytes: prospects for keratinocyte gene therapy. Hum. Gene Ther., v. 5, p. 1241-1248, 1994.

FERRARI, S., PELlEGRINI, G., MATSUI, T., MAVILIO, F. AND DE LUCA, M. Gene therapy in combination with tissue engineering to treat epidermolysis bullosa. Expert Opin. Biol. Ther., v. 6, p. 367-378, 2006.

FERRARI, S., PELLEGRINI, G., MAVILIO, F. AND DE LUCA, M. Gene therapy approaches for epidermolysis bullosa. Clin. Dermatol., v. 23, p. 430-436, 2005.

GARLICK, J.A. AND TAICHMAN, L.B. Effect of TGF- $\beta 1$ on re-epithelization of human keratinocytes in vitro: an organotypic model. J. Invest. Dermatol., v. 103, p. 554-559, 1994.

GERRARD, A.J., HUDSON, D.L., BROWNLEE, G.G. AND WATT, F.M. Towards gene therapy for haemophilia B using primary human keratinocytes. Nature Genet., v. 3, p. 180-183, 1993.

GHAZIZADEH S. AND TAICHMAN L.B. Virus-mediated gene transfer for cutaneous gene therapy. Hum. Gene Ther., v. 11, p. 2247-2251, 2000. 
GHAZIZADEH, S., KALISH, R.S. AND TAICHMAN, L.B. Immune-mediated loss of transgene expression in skin: implications for cutaneous gene therapy. Mol. Ther., v. 7, p. 296-303, 2003.

GREEN, H., KEHINDE, O. AND THOMAS J. Growth of cultured human epidermal cells into multiple epithelia suitable for grafting. Proc. Natl. Acad. Sci. USA, v. 76, p. 5665-5668, 1979.

HACEIN-BEY-ABINA, S., VON KALLE, C., SCHMIDT, M., LE DEIST, F., WULFFRAAT, N., MCINTYRE, E., RADFORD, I., VILLEVAL, J.L., FRASER, C.C., CAVAZZANA-CALVO, M. AND FISHER, A. A serious adverse event after successful gene therapy for $X$-linked severe combined immunodeficiency. $\mathbf{N}$. Engl. J. Med., v. 348, p. 255-256, $2003 a$.

HACEIN-BEY-ABINA, S., VON KALLE, C., SCHMIDT, M., MCCORMACK, M.P., WULFFRAAT, N., LEBOULCH, P., LIM, A., OSBORNE, C.S., PAWLIUK, R., MORILLON, E., SORENSEN, R., FORSTER, A., FRASER, P., COHEN, J.I., DE SAINT BASILE, G., ALEXANDER, I., WINTERGERST, U., FREBOURG, T., AURIAS, A., STOPPA-LYONNET, D., ROMANA, S., RADFORD-WEISS, I., GROSS, F., VALENSI, F., DELABESSE, E., MACINTYRE, E., SIGAUX, F., SOULIER, J., LEIVA, L.E., WISSLER, M., PRINZ, C., RABBITTS, T.H., LE DEIST, F., FISHER, A. AND CAVAZZANA-CALVO, M. LMO2-associated clonal T cell proliferation in two patients after gene therapy for SCID-X1. Science, v. 302, p. 415-419, 2003b.

HEARTLEIN, M.W., ROMAN, V.A., JIANG, J., SELLERS, J.W., ZULIANI, A.M., TRECO, D.A. AND SELDEN, R.F. Long-term production and delivery of human growth hormone in vivo. Proc. Assoc. Am. Physicians, v. 91, p. 10967-10971, 1994.

HENGGE, U.R. AND BARDENHEUER, W. Gene therapy and the skin. Amer. J. Med. Genet. Part C (Semin. Med. Genet.), v. 131C, p. 93-100, 2004. 
HENGGE, U.R. Gene therapy progress and prospects: the skin - easily accessible, but still far away. Gene Ther; v. 13, p. 1555-1563, 2006.

JENSEN, U.B., JENSEN, T.G., JENSEN, P.K.A., RYGAARD, J., HANSEN, B.S., FOGH, J., KOLVRAA, S. AND BOLUND, L. Gene transfer into culture human epidermis and its transplantation onto immunodeficient mice: an experimental model for somatic gene therapy. J. Invest. Dermatol., v. 103, p. 391-394, 1994.

JENSEN, T.G. Gene transfer into human epidermis as an experimental model for somatic gene transfer. Dan. Med. Bull., v. 51, p. 155-166, $2004 a$.

JENSEN TG. Strategies for long-term gene expression in the skin to treat metabolic disorders. Expert Opin. Biol. Ther., v. 4, p. 677-682, 2004b.

KIKUCHI Y., TAMAI K. AND KANEDA Y. Cutaneous gene therapy. J. Dermatol. Sci., v. 50, p. 87-98, 2007.

KIURU, M. AND CRYSTAL, R.G. Progress and prospects for performance and appearance enhancement. Gene Ther., v. 15, p. 329-337, 2008.

KLERMAN, E.B., ADLER, G.KK, JIN, M.S., MALISZEWSKI, A.M. AND BROWN, E.N. A statistical model of diurnal variation in human growth hormone. Am. J. Physiol. Endocrinol. Metab., v. 285, p. 1118-1126, 2003.

KOLODKA T.M., GARLICK J.A. AND TAICHMAN, L.B. Evidence for keratinocyte stem cells in vitro: long term engraftment and persistence of transgene expression from retrovirus-transduced keratinocytes. Proc. Natl. Acad. Sc.i USA, v 95, p. 4356-4361, 1998.

KRUEGER, G.G., JORGENSEN, C.M., MATSUNAMI, N., MORGAN, J.R., LIIMATA, A., MELONI-EHRIG, A., SHEPARD, R., AND PETERSEN, M.J. Persistent transgene expression and normal differentiation of immortalized human keratinocytes in vivo. J. Invest. Dermatol., v. 112, p. 233-239, 1999. 
LI, Y.C., GUAN, C.T., ZHAO, K.Q., CHEN, Z.L. AND LI, T.L. Pharmacokinetics of lactosaminated recombinant human growth hormone in mice. Acta Pharmacol. Sin., v. 22, p. 450-454, 2001.

MARKOWITZ, D. GOFF, S. AND BANK. A. A safe packaging line for gene transfer: Separating viral genes on two different plasmids. J. Virol., v. 62, p. 11201124, 1988a.

MARKOWITZ, D. GOFF, S. AND BANK. A Construction and use of a safe and efficient amphotropic packaging cell line. J. Virol., v. 167, p. 400-406, 1988 b.

MARMARY, Y., PARLOW, A.F., GOLDSMITH, C.M., HE, X., WELLNER, R.B., SATOMURA, K., KRIETE, M.F., ROBEY, P.G., NIEMAN, L.K., AND BAUM, B.J. Construction and in vivo efficacy of a replication-deficient recombinant adenovirus encoding murine growth hormone. Endocrinology, v. 140, p. 260-265, 1999.

MATHOR, M.B., FERRARI, G., DELlAMBRA, E., CILLI, M., MAVILIO, F., CANCEDDA, R., AND DE LUCA, M. Clonal analysis of stably transduced human epidermal stem cells in culture. Proc. Natl. Acad. Sci. USA, v. 93, p. 1037110376, 1996.

MAVILIO F, PELLEGRINI G, FERRARI S, DI NUNZIO, F., DI IORIO, E., RECCHIA, A. MARUGGI, G., FERRARI, G., PROVASI, E., BONINI, C., CAPURRO, S., CONTI, A., MAGNONI, C., GIANETTI, A. AND DE LUCA, M. Correction of junctional epidermolysis bullosa by transplantation of genetically modified epidermal stem cells. Nat. Med., v. 12, p. 1397-1402, 2006.

MELMED, S. AND KLEINBERG, D.L. (2003). IN WILLIAMS TEXTBOOK OF ENDOCRINOLOGY. P.R. LARSEN, H.M. KRONENBERG, S. MELMED, AND K.S. POLONSKY, eds. (WB Saunders Co, Philadelphia, PE) p.p. 177-279.

MILLER, A.D., MILLER, D.G., GARCIA, J.V. AND LYNCH, C.M. Use of retroviral vectors for gene transfer and expression. Methods Enzymol., v. 217, p. 581-599, 1993. 
MORGAN, J.R., BARRANDON, Y., GREEN, H. AND MULLIGAN, R.C. Expression of an exogenous growth hormone gene by transplantable human epidermal cells. Science, v. 237, p. 1476-1479, 1987.

MORGAN, R.A. AND ANDERSON W.F. Human gene therapy. Annu. Rev. Biochem., v. 62, p. 191-217, 1993.

MULLIGAN, R.C. The basic science of gene therapy. Science, v. 260, p. 926-932, 1993.

NARDI, N.B., TEIXEIRA, L.A.K. AND SILVA, E.F.A. Gene therapy. Ciência \& Saúde Coletiva, v. 7, p. 109-116, 2002.

OLIVEIRA, J.E., SOARES, C.R.J., PERONI, C.N., GIMBO, E., CAMARGO, I.M.C., MORGANTI, L., BELLINI, M.H., AFFONSO, R., ARKATEN, R.R., BARTOLINI, P. AND RIBELA, M.T.C.P. High-yield purification of byosynthetic human growth hormone secreted in Escherichia coli periplasmic space. J. Chromat. A, v. 852, p. 441-450, 1999.

PARENTEAU, N., SABOlinSKI, M., PROSKY, S., NOLTE, C., OLESON, M., KRIWET, K, AND BILBO, P. Biological and physical factors influencing the successful engraftment of a cultured human skin substitute. Biotechnol. Bioeng., v. 52, p. 3-14, 1996.

PERONI, C.N., GOUT, P.W. AND BARTOLINI, P. Animal models for growth hormone gene therapy. Curr. Gene Ther., v. 5, 493-509, 2005.

PERONI, C.N., CECCHI, C.R., DAMIANI, D., SOARES, C.R.J., RIBELA, M.T.C.P., ARKATEN, R.R., AND BARTOLINI, P. High-level secretion of growth hormone by retrovirally transduced primary human keratinocytes: prospects for an animal model of cutaneous gene therapy. Molecular Biotechnology, v. 34, p. 239-245, 2006. 
PERONI, C.N., CECCHI, C.R., ROSAURO, C.W., NONOGAKI, S., BOCCARDO, E. AND BARTOLINI, P. Secretion of mouse growth hormone by transduced primary human keratinocytes: prospects for an animal model of cutaneous gene therapy. J. Gene Med., v.10, p. 734-743, 2008.

PRUD'HOMME, G.J.; GLINKA, Y.; KHAN, A.S.; DRAGLIA-AKLI, R.; Electroporation-Enhanced Nonviral Gene Transfer for the Prevention or Treatment of Immunological, Endocrine and Neoplastic Diseases. Curr. Gene Ther., v. 6, p. 243-273, 2006.

PRUD'HOMME, G.J; DRAGLIA-AKLI, R.; WANG, Q. Plasmid-based gene therapy of diabetes mellitus. Gene Ther., v.14, p. 553-564, 2007.

RAPER, S.E., CHIRMULE, N., LEE, F.S., WIVEL, N.A., BAGG, A., GAO, G.P., WILSON, J.M., AND BATSHAW, M.L. Fatal systemic inflammatory response syndrome in an ornithine transcarbamylase deficient patient following adenoviral gene transfer. Mol. Genet. Metab., v. 80, p. 148-158, 2003.

RATANAMART J. \& SHAW J.A.M. Plasmid-mediated muscle-targed gene therapy of circulating therapeutic protein replacement: a tale of the tortoise and the hare? Curr. Gene Ther., v.6, p. 93-110, 2006.

RHEINWALD, J.G. AND BECKETT, M.A. Tumorigenic keratinocyte lines requiring anchorage and fibroblast support cultured from human squamous cell carcinomas. Cancer Res., v. 41, p. 1657-1663, 1981.

RIBELA, M.T.C.P., MURATA, Y., MORGANTI, L., TONIOLO, D. AND BARTOLINI, $P$. The use of recombinant human growth hormone for radioiodination and standard preparation in radioimmunoassay. J. Immunol. Methods, v. 159, p. 269274, 1993.

RIVERA, V.M., YE, X., COURAGE, N.L., SACHAR, J, CERASOLI JR, F., WILSON, J.M. AND GILMAN, M. Long-term regulated expression of growth 
hormone in mice after intramuscular gene transfer. Proc. Natl. Acad. Sci. USA, v. 96, p. 8657-8662, 1999.

ROBBINS, P.D., TAHARA, H. AND GHIVIZZANI, S.C. Viral vectors for gene therapy. Trends Biotechnol., v. 16, p. 35-40, 1998.

RODBARD, D. Statistical estimation of the minimal detectable concentration ("sensitivity") for radioligand asays. Anal. Biochem., v.90, p.1-12, 1978.

ROMANO, G., MICHELL, P., PACILIO, C. AND GIORDANO, A. Latest development in gene transfer technology: achievements, perspectives, and controversies over therapeutic applications. Stem Cells, v.18, p. 19-39, 2000.

ROSAURO, C.W. Altos níveis de expressão de hormônio de crescimento de camundongo em queratinócitos humanos visando a obtenção de um modelo animal de terapia gênica. 2003. Tese (Mestrado) - Instituto de Pesquisas Energéticas e Nucleares, São Paulo.

SONDERGAARD, M., DAGNAES-HANSEN, F., FLYVBJERG, A. AND JENSEN, T.G. Normalization of growth in hypophysectomized mice using hydrodynamic transfer of the human growth hormone gene. Am. J. Physiol. Endocrinol. Metab., v. 285, p. E427-E432, 2003.

ST. GEORGE, J.A. Gene therapy progress and prospects: adenoviral vectors. Gene Ther., v. 10, p.1135-1141, 2003.

STOCKSCHLADER MAR, SCHUENING FG, GRAHAM TC AND STORB, R. Transplantation of retrovirus-transduced canine keratinocytes expressing the $\beta$ galactosidase gene. Gene Ther., v. 1, p. 317-322, 1994.

TAICHMAN, L.B. Systemic replacement therapy from genetically modified epidermal keratinocytes. Proc. Assoc. Am. Physicians, v. 111, p. 206-210, 1999. 
TEUMER, J., LINDAHL, A. AND GREEN, H. Human growth hormone in the blood of athymic mice grafted with cultures of hormone-secreting human keratinocytes. FASEB J., v. 4, p. 3245-3250, 1990.

TOMANIN, R. AND SCARPA, M. Why do we need new gene therapy viral vectors? Characteristics, limitations and future perspectives of viral vector transduction. Curr. Gene Ther., v. 4, p. 357-37, 2004.

VAN GAAL, E.V.B., HENNINK, W.E., CROMMELIN D.J.A. AND MASTROBATTISTA E. Plasmid engineering for controlled and sustained gene expression for nonviral gene therapy. Pharm. Res., v. 23, p. 1053-1074, 2006.

VOGT, P.M., THOMPSON, S., ANDREE, C., LIU, P., BREUING, K., HATZIS, D., BROWN, H., MULLIGAN, R.C. AND ERIKSSON, E. Genetically modified keratinocytes transplanted to wounds reconstitute the epidermis. Proc. Natl. Acad. Sci. USA, v. 91, p. 9307-9311, 1994.

YI, Y., HAHM, S.H. AND LEE, K.H. Retroviral gene therapy: safety issues and possible solutions. Curr. Gene Ther., 5: 25-35, 2005. 